\title{
Factors in Decisions to Make, Purchase, and Use On-board Safety Technologies
}

\author{
Task 5.3 Report
}

U.S. Department of Transportation 


\section{Foreword}

In support of its goal to reduce large truck-related fatality rates, FMCSA plans to facilitate the deployment of Intelligent Vehicle Initiative (IVI) technologies that have shown a potential to improve the safety of commercial vehicle operations (CVO) and provide safety benefits to society as a whole.

The IVI is part of the Intelligent Transportation Systems (ITS) program of the U.S. Department of Transportation (USDOT). FMCSA administers the program for commercial motor vehicles. Under the IVI program, three field operational tests (FOTs) of crash avoidance technologies are completed or underway: Volvo Test, Freightliner Test, and the Mack Test.

Following the successful completion of the FOTs, FMCSA will be committed to facilitating the deployment of safety technologies for commercial motor vehicles that will improve safety. Acceptance by motor carriers and drivers will be vital to successful deployment and reduction of commercial motor vehicle fatalities and injuries.

An important part of this overall project is to understand what motivates the key stakeholders when making decisions to manufacture, buy, or use on-board safety technologies. The results in this report address that part of the overall project.

Although the report can be helpful to the general public in understanding on-board safety systems, it is primarily targeted towards commercial motor carriers and their drivers.

This publication is considered a final report and does not supersede another publication.

\section{Notice}

This document is disseminated under the sponsorship of the Department of Transportation in the interest of information exchange. The United States Government assumes no liability for its contents or use thereof.

This report does not constitute a standard, specification, or regulation.

The United States Government does not endorse products or manufacturers. Trade or manufacturers' names appear herein only because they are considered essential to the object of this document. 


\section{Technical Report Documentation Page (Form 1700.7)}

\begin{tabular}{|c|c|c|c|}
\hline $\begin{array}{l}\text { 1. Report No. } \\
\text { FMCSA-MCRT-06-003 }\end{array}$ & 2. Government Accession No. & \multicolumn{2}{|c|}{ 3. Recipient's Catalog No. } \\
\hline \multicolumn{2}{|c|}{$\begin{array}{l}\text { 4. Title and Subtitle: } \\
\text { Factors in Decisions to Make, Purchase, and Use On-board Safety Technologies }\end{array}$} & \multicolumn{2}{|c|}{ 5. Report Date: December 2005} \\
\hline & & \multicolumn{2}{|c|}{ 6. Performing Organization Code } \\
\hline \multicolumn{2}{|c|}{$\begin{array}{l}\text { 7. Author(s): } \\
\text { David Ball, Scott Versluis, R.A. Hendrickson, Jerry Pittenger, Boni Frank, and Amy } \\
\text { Stewart, with Battelle, and Dan Murray, with ATRI. }\end{array}$} & \multicolumn{2}{|c|}{ 8. Performing Organization Report No } \\
\hline \multirow{2}{*}{\multicolumn{2}{|c|}{$\begin{array}{l}\text { 9. Performing Organization Name and Address: } \\
\text { Battelle } \\
505 \text { King Avenue } \\
\text { Columbus, OH } 43201-2693\end{array}$}} & \multicolumn{2}{|l|}{ 10. Work Unit No. } \\
\hline & & \multicolumn{2}{|c|}{$\begin{array}{l}\text { 11. Contract or Grant No. } \\
\text { DTFH61-96-C-00077 }\end{array}$} \\
\hline \multirow{2}{*}{$\begin{array}{l}\text { 12. Sponsoring Agency Name and A } \\
\text { Federal Motor Carrier Safety Admini } \\
\text { Office of Research and Analysis } \\
400 \text { Virginia Avenue, SW, Suite } 600 \\
\text { Washington, DC } 20024\end{array}$} & & \multicolumn{2}{|c|}{$\begin{array}{l}\text { 13. Type of Report and Period Covered } \\
\text { Final Report, August 2001-July } 2005\end{array}$} \\
\hline & & \multicolumn{2}{|c|}{$\begin{array}{l}\text { 14. Sponsoring Agency Code } \\
\text { FMCSA }\end{array}$} \\
\hline \multicolumn{4}{|c|}{$\begin{array}{l}\text { 15. Supplementary Notes: } \\
\text { The Contracting Officer’s Technical Representative was Amy Houser, FMCSA Office of Research and Analysis. }\end{array}$} \\
\hline \multicolumn{4}{|c|}{$\begin{array}{l}\text { In support of its goal to reduce large truck-related fatalities and crashes, FMCSA plans to facilitate the deployment of Intelligent Vehicle } \\
\text { Initiative (IVI) technologies that have shown a potential to improve the safety of commercial vehicle operations (CVO) and provide safety } \\
\text { benefits to society as a whole. }\end{array}$} \\
\hline \multicolumn{4}{|c|}{$\begin{array}{l}\text { The IVI is part of the Intelligent Transportation Systems (ITS) program of the U.S. Department of Transportation (USDOT). FMCSA } \\
\text { administers the program for commercial motor vehicles. Under the IVI program, three field operational tests (FOTs) of crash avoidance } \\
\text { technologies are completed or underway: Volvo Test, Freightliner Test, and the Mack Test. }\end{array}$} \\
\hline \multicolumn{4}{|c|}{$\begin{array}{l}\text { Following the successful completion of the FOTs, FMCSA will be committed to facilitating the deployment of safety technologies for } \\
\text { commercial motor vehicles that will improve safety. Acceptance by motor carriers and drivers will be vital to successful deployment and } \\
\text { reduction of commercial motor vehicle fatalities and injuries. }\end{array}$} \\
\hline \multicolumn{4}{|c|}{$\begin{array}{l}\text { An important part of this overall project is to understand what motivates the key stakeholders when making decisions to manufacture, buy, } \\
\text { or use on-board safety technologies. The results in this report address that part of the overall project. }\end{array}$} \\
\hline \multicolumn{2}{|c|}{$\begin{array}{l}\text { 17. Key Words: } \\
\text { Adaptive Cruise Control, Collision Warning System, Electronically Controlled Braking } \\
\text { System, Crash Avoidance, Deployment, Field Operational Test, FOT, IVI, Intelligent } \\
\text { Transportation Systems, Intelligent Vehicle Initiative, Lane Departure, On-board, Safety } \\
\text { Technologies, Roll Advisor and Controller }\end{array}$} & \multicolumn{2}{|c|}{$\begin{array}{l}\text { 18. Distribution Statement } \\
\text { No restrictions }\end{array}$} \\
\hline $\begin{array}{l}\text { 19. Security Classif. (of this report) } \\
\text { Unclassified }\end{array}$ & $\begin{array}{l}\text { 20. Security Classif. (of this page) } \\
\text { Unclassified }\end{array}$ & $\begin{array}{l}\text { 21. No. of Pages: } \\
90\end{array}$ & 22. Price \\
\hline
\end{tabular}




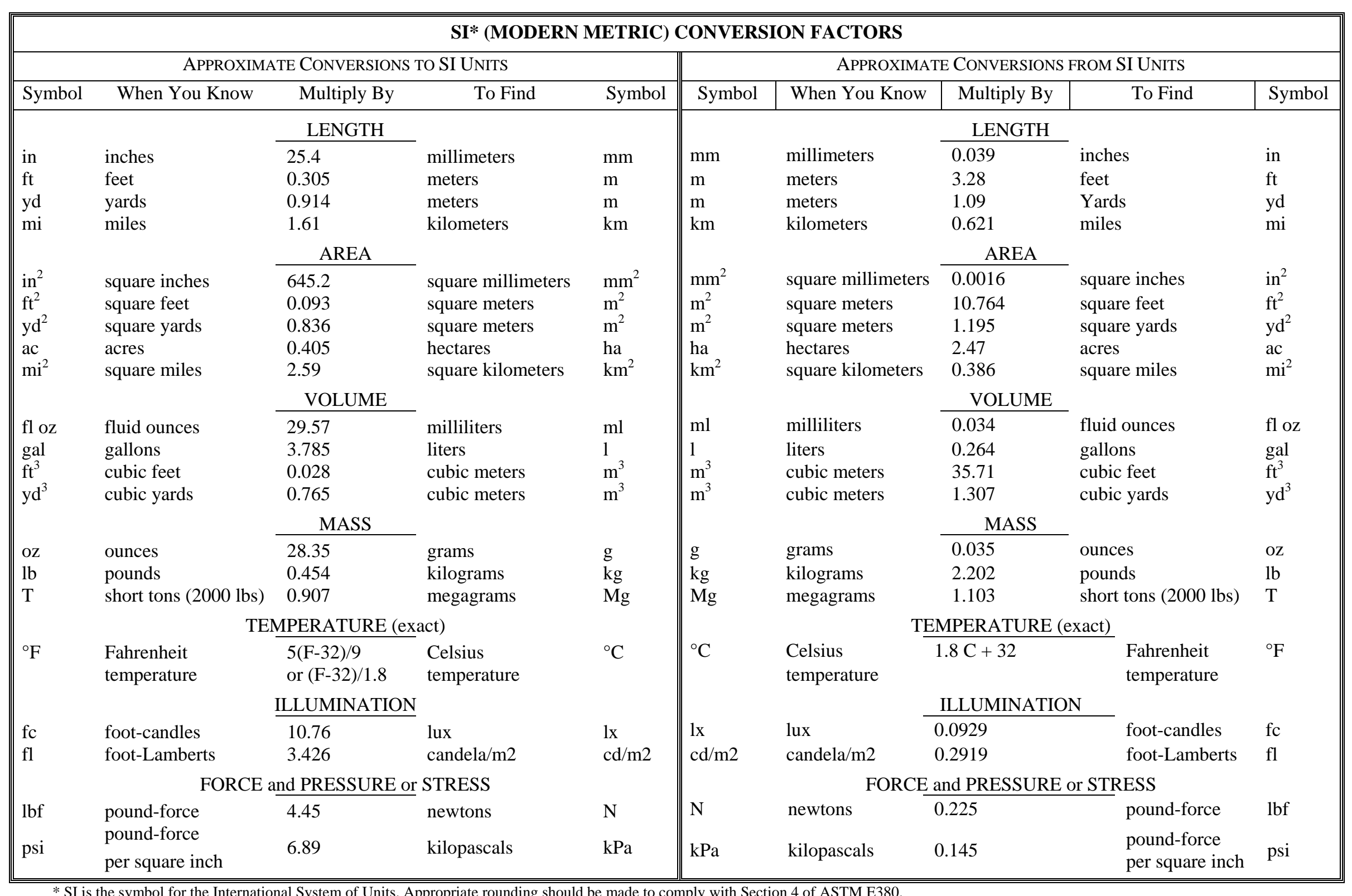

\footnotetext{
* SI is the symbol for the International System of Units. Appropriate rounding should be made to comply with Section 4 of ASTM E380.
} 


\section{Table of Contents}

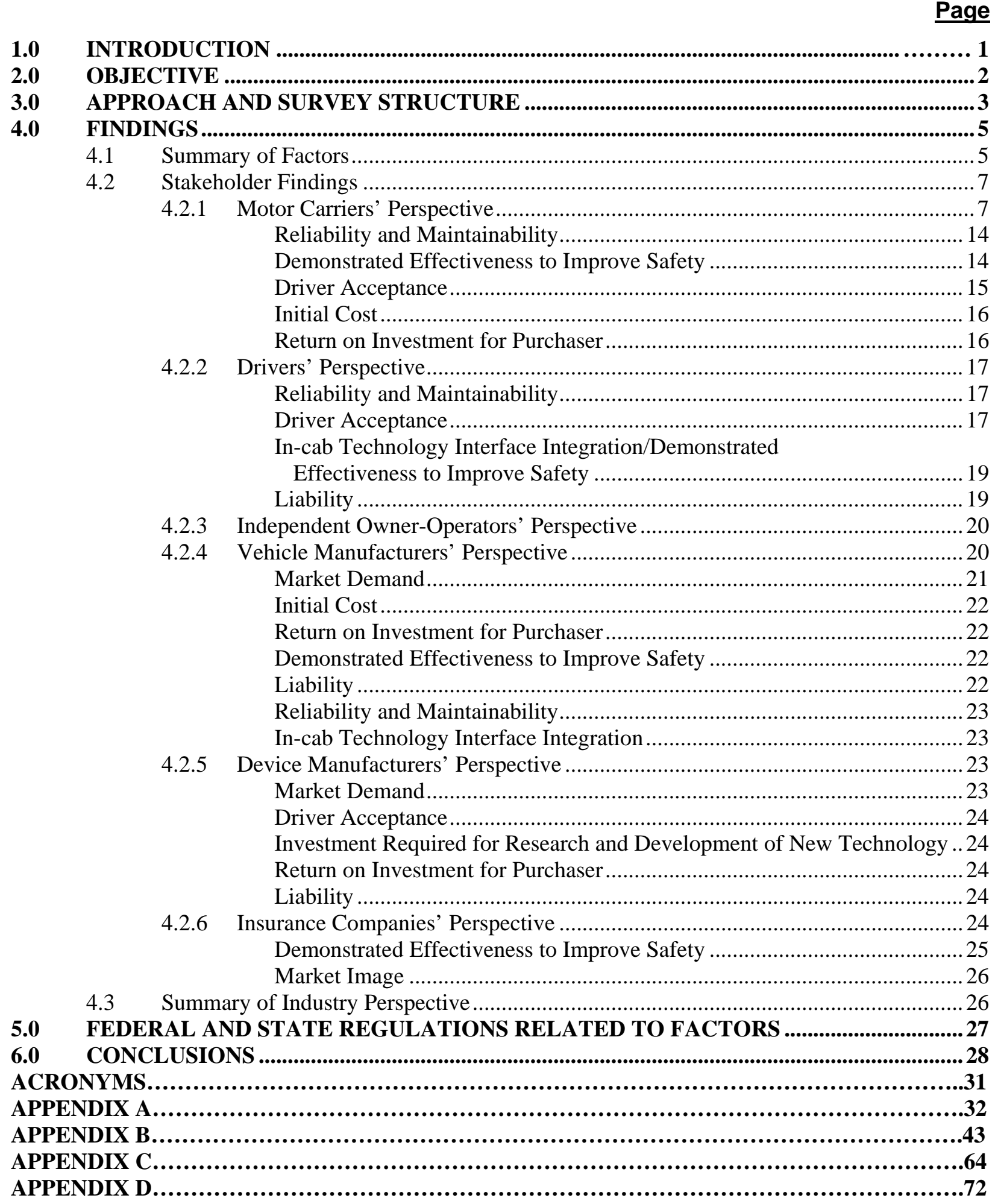




\section{Introduction}

In 2001, there were 4,431 fatal crashes involving large trucks (gross vehicle weight rating (GVWR) greater than 10,000 pounds) resulting in 5,082 fatalities or 2.4 fatalities per 100 million miles traveled, according to Federal Motor Carrier Safety Administration (FMCSA) statistics. ${ }^{1}$ Truck occupants accounted for 704 of those fatalities.

These statistics represent a decrease of nearly 4 percent in fatal crashes, 5.8 percent in fatalities, and 14.3 percent in fatalities per 100 million miles since 1997, the beginning of a recent trend of reduced fatal crashes and fatalities involving large trucks. Bill Graves, President and CEO of the American Trucking Associations (ATA), cited better training of truck drivers and better education of automobile drivers as helping with this trend. ${ }^{2}$

Despite this recent downward trend, crashes involving large trucks result in significant financial burden. "Trucks are involved in less than one percent of all motor vehicle crashes in the United States ... But the cost of even one accident can be enough to bankrupt a fleet,” Fleet Owner recently reported. ${ }^{3}$ In 2000, crashes involving large trucks are estimated to have cost a total of $\$ 19.56$ billion: $\$ 9.6$ billion for quality of life, $\$ 6.6$ billion for lost productivity, $\$ 2.2$ billion for property damage, $\$ 1.1$ billion for medical, and $\$ 0.06$ billion for emergency services. ${ }^{4}$

A priority goal of FMCSA is to further reduce the large truck-related fatality rate to 1.65 per 100 million truck-miles by the year 2008. In support of this goal, FMCSA plans to facilitate the deployment of Intelligent Vehicle Initiative (IVI) technologies that have shown a potential to improve the safety of commercial vehicle operations (CVO) and provide safety benefits to society as a whole.

The IVI is part of the Intelligent Transportation Systems (ITS) program of the U.S. Department of Transportation (USDOT). FMCSA administers the program for commercial motor vehicles. Under the IVI program, the following three field operational tests (FOTs) of crash avoidance technologies are completed or underway:

- Volvo Test: The objective is to test the operational effectiveness of the bundled advanced safety system of the Electronically Controlled Braking system (ECBS), Front end Collision Warning System (CWS), and Adaptive Cruise Control (ACC). The Doppler radar-based CWS warns truck drivers of imminent slower moving vehicles and other hazards on the road. This system tracks truck speed, adjusts the warning distance, and records vehicle data. The CWS with ACC (CWS/ACC) will be the technology that is focused on for deployment.

\footnotetext{
1“'Large Truck Crash Facts,” FMCSA, January 2003

(http://ai.volpe.dot.gov/CrashProfile/NationalCrashProfileMain.asp).

${ }^{2}$ Transport Topics, July 2003.

3“Cutting Crash Costs,” FleetOwner, Sean Kilcarr , February 1, 2003 (http://fleetowner.com/ar/fleet_cutting_crash_costs/index.htm).

${ }^{4}$ Presentation by Annette M. Sandberg, FMCSA Acting Administrator, $3{ }^{\text {rd }}$ National Intelligent Vehicle Meeting, panel presentation, June 25, 2003.
} 
- Freightliner Test: The objective was to test the operational effectiveness of the Roll Stability Advisor (RSA) and Roll Stability Controller (RSC). The RSA is an on-board device that provides feedback about the truck's rollover threshold and the RSC provides an active response to hazardous conditions. The rollover prevention system tested is intended to improve driver performance and vehicle stability in turns, leading to a reduction in rollovers and other types of crashes such as single vehicle roadway departures. Together, the RSA and RSC components are referred to as the Roll Advisor and Controller (RA\&C), which will be the primary technology discussed in this report.

- Mack Test: The objective is to test the operational effectiveness of the Lane Departure Warning System (LDWS). This system uses vision processing to "read" the road ahead and note the position of the host vehicle in the lane. An indication of lane keeping accuracy is provided, and alarms will sound if the vehicle strays over the edge of the lane. This FOT focuses on single vehicle run-off road crashes. The LDWS will be the technology focused on for deployment.

Following the successful completion of the FOTs, FMCSA will be committed to facilitating the deployment of safety technologies for commercial motor vehicles that will improve safety. Acceptance by motor carriers and drivers will be vital to successful deployment and reduction of commercial motor vehicle fatalities and injuries.

An important part of this overall project is to understand what motivates the key stakeholders when making decisions to manufacture, buy, or use on-board safety technologies. The results in this report address that part of the overall project.

\subsection{Objective}

The objective of this task is to identify, list, and assess the decision-making factors that stakeholders, including motor vehicle carriers, drivers, and manufacturers, employ when deciding to make, purchase, or use on-board safety technologies. This information was obtained by surveying stakeholders including commercial motor vehicle carriers, drivers, truck original equipment manufacturers (OEMs), device manufacturers (vendors), insurers, and associations. As a result of these surveys and meetings, broad strategies were identified to accelerate the deployment of each on-board safety technology. Supporting information for this document was also obtained from the American Transportation Research Institute (ATRI) and an expert panel workshop held on August 7, 2003, sponsored by FMCSA.

The results of this task will be used in other tasks to determine actions FMCSA may take to

1) create an operational environment that encourages stakeholders to make, purchase, or use,

2) mitigate negative factors or obstacles to the use of,

3) identify incentives and disincentives for the use of, and

4) implement a technology deployment plan for on-board safety technologies. 


\subsection{Approach and Survey Structure}

After analyzing the alternatives for collecting information, structured interviews were conducted with stakeholders using a consistent one-on-one interview process. Battelle interviewers assured stakeholder participants of anonymity to foster an atmosphere conducive to frank discussions. Since the stakeholders were geographically dispersed, most of them were interviewed by telephone. The principal exception was the drivers, including the independent owner-operators, who were interviewed person-to-person at truckstops and driver-training sessions. An interview guide (Appendix A) was constructed to provide a structured approach to the discussions. The guide was designed to ensure that the interviewers asked the right questions to accomplish the objective of this study. A separate questionnaire was developed for the drivers and independent owner-operators, which is also included in Appendix A.

Table 1 summarizes the makeup of the interview survey. Telephone interviews were conducted with 19 motor carrier representatives (both private and for hire including one association with a carrier perspective), five insurance companies, two associations, one driver-training program, six OEM vehicle manufacturers, and three on-board safety technology vendors.

The motor carriers interviewed represented various types of transport (food, produce, hazmat, liquids, general freight, and refrigerated products), both public and private companies, and various sizes of operation. The carrier fleets ranged in size from five of the largest in the United States with over 10,000 power units each to smaller fleets with eight having fewer than 500 and four having less than 100 power units. Both corporate fleets and companies using independently owned trucks were included as were those having union and non-union organizations. It should be noted that there are over 600,000 registered carriers in the United States and although the survey sample was small by comparison (19), it is believed to represent a broad cross section of the population as a whole. In particular the survey sample included 10 hazmat-certified carriers and 8 that haul chemicals, liquids, and gases. ${ }^{5}$ Both of these are considered good target markets for on-board safety technologies.

Twenty drivers were interviewed, including six owner-operators. The length of commercial experience for the drivers interviewed ranged from three to 48 years with an average of 24 years. On the average, the drivers in the survey group have been with the same company for 9 years, although several were new to their companies and one had been with the same company for 46 years. All major types of trucks were included in the survey, with the exception of auto and livestock transporters, and notably included 15 hazmat-certified drivers and 13 who drive tankers, both considered attractive markets for on-board safety technologies. The survey sample also included drivers with longer routes (seven had routes of 400 miles or more) and shorter routes (five had routes of less than 100 miles). It was assumed a priori that independent owneroperators would be motivated somewhat differently from carrier-employed drivers due to their lack of financial backing from a large carrier.

\footnotetext{
5“Active Carriers by Fleet Size with Percentages - All Active Carriers,” Office of Motor Carriers Management Information System, Special Report LS50B901, March 4, 2002.
} 
Table 1. Stakeholder Interview Summary

\begin{tabular}{|c|c|c|c|}
\hline $\begin{array}{c}\text { Stakeholder } \\
\text { Classification } \\
\end{array}$ & $\begin{array}{l}\text { Telephone } \\
\text { Interviews } \\
\end{array}$ & $\begin{array}{c}\text { Personal } \\
\text { Interviews }\end{array}$ & Comments \\
\hline Carriers & 19 & & $\begin{array}{l}\text { - } 5 \text { of the top } 10 \text { carriers in the U.S. and Canada } \\
\text { (including the top two) }^{6} \\
\text { - } 8 \text { were hazmat-certified } \\
16 \text { were for hire, } 2 \text { private, } 1 \text { NY State truck } \\
\text { association }\end{array}$ \\
\hline $\begin{array}{l}\text { OEM Vehicle } \\
\text { Manufacturers }\end{array}$ & 6 & & $\begin{array}{ll}\text { Freightliner } \\
\text { - } \text { Volvo } \\
\text { : } \text { PACCAR } \\
\text { - Osternational } \\
\text { - Navistar } \\
\text {. }\end{array}$ \\
\hline Product Vendors & 3 & & $\begin{array}{ll}\text { - } & \text { Meritor WABCO } \\
\text { - } & \text { Bendix } \\
\text { - } & \text { TRW }\end{array}$ \\
\hline Drivers & & 20 & - Includes several owner-operators \\
\hline $\begin{array}{l}\text { Insurance } \\
\text { Companies }\end{array}$ & 5 & & $\begin{array}{l}\text { - Liberty Mutual } \\
\text { - } \text { Hailer, Fryer and Coon } \\
\text { - St. Paul Companies } \\
\text { - } \text { Marsh Inc. } \\
\end{array}$ \\
\hline Totals & 33 & 20 & \\
\hline
\end{tabular}

Manufacturers of Class 7 (26,001 to 33,000 lbs GVWR) and Class 8 (33,001 lbs GVWR and over) trucks and vendors (component manufacturers) were interviewed. Multiple interviews were conducted with almost all of the participating truck manufacturers. These manufacturers represent the majority of the industry's manufacturers of Class 7 and Class 8 trucks.

In addition to the above interviews, an expert panel workshop was held on August 7, 2003 in Washington, DC, specifically to probe stakeholder opinions on deployment of the RA\&C. The results of that workshop are included in this report as Appendix D and incorporated in the findings.

The interview survey was qualitatively structured to represent a broad cross section of the various stakeholder groups. As such, it is not a statistical sample of any one stakeholder group or of the industry as a whole. The stakeholder groups interviewed are generally representative of those industry segments involved in making or influencing the decision to make, use, or buy onboard safety technologies. In some cases, the survey group is skewed towards respondents that are either already involved with on-board safety technology or were considered to be attractive

\footnotetext{
${ }^{6}$ Taken from list of the top 100 for hire carriers published by Transport Topics, July 2003.
} 
future markets for it such as larger carriers and those having tanker fleets, especially those that are hazmat-certified. For instance:

- All three vendors interviewed are already working on various types of on-board safety technologies.

- Although most of the major truck OEMs selling in the United States were included in the interview survey (six in all), three of them are involved in the FOTs for on-board safety technologies (Freightliner, Mack, and Volvo).

- Most of the carriers included in this interview survey are large by industry standards, having more than 100 power units each while most (over 80 percent) of the registered carriers in the United States have fewer than 20 power units each. ${ }^{7}$ Also, over half of the carrier interview sample was hazmat-certified (10 carriers) and nearly half of the sample haul gases, liquids, and chemicals (8 carriers).

- Most of the drivers interviewed (15 out of 20) are hazmat-certified and drive tankers.

Appendix C provides information about the stakeholders who participated in the interview process.

\subsection{Findings}

The findings for this task are based on the limited sample of industry respondents interviewed (as described in Table 1 and Appendix C) combined with the results of an expert panel workshop held on August 7, 2003 (see Appendix D) and the assistance and review of ATRI throughout the project. A summary of the interview results is provided in Appendix B.

\subsection{Summary of Factors}

Listed below are the factors involved in making, using, and buying decisions for on-board safety technologies based on the findings of this task. These factors and their definitions were developed from the comments received in the interview survey, the August 7 expert panel workshop, and input from ATRI and others involved in the conduct of this study.

- Return on Investment for Purchaser (the carrier) is considered an important factor for sustained commercial success for on-board safety technologies. A positive ROI is a significant factor when carriers decide to purchase on-board safety technologies according to most of the carriers interviewed.

- Demonstrated Effectiveness to Improve Safety through the use of on-board safety systems essentially represents the benefits that offset the purchase and other costs to yield a positive ROI. This factor is important to all stakeholders surveyed.

\footnotetext{
7“Active Carriers by Fleet Size with Percentages - All Active Carriers,” Office of Motor Carriers Management Information System, Special Report LS50B901, March 4, 2002.
} 
- Reliability and Maintainability is also a significant factor (mentioned in a number of interviews) and is considered important to buyers (carriers) and manufacturers (OEMs and vendors).

- Liability is a potential concern to a number of stakeholders interviewed, especially when combined with the discoverable nature of the data stored by some on-board safety technologies. While the absence of liability concerns is not sufficient to drive deployment, the presence of other concerns in this area could impede deployment, therefore making it a significant factor as well. Liability concerns are an important factor to carriers, drivers, and manufacturers interviewed.

- Market Demand to some extent is a result of the above factors but also depends on awareness of the technology along with acceptance and belief in its value. Market demand is a factor that interviewed manufacturers considered when introducing a new product.

- Initial Cost is an important adjunct to ROI. Too high a purchase cost not only makes it difficult for the purchaser to believe there is a positive ROI but also may strain the ability of the purchaser to raise the needed capital for the purchase. The carriers interviewed indicated that affordability and payback influence the decision to purchase the new technology.

- Investment Required for Research and Development of New Technology, such as onboard safety technologies for OEMs and vendors, is fundamental to their business plan. The combination of investment needed, expected sales volume, purchase cost, and cost of production make up the potential profitability for the vendor.

- Market Image is a factor, at least in initial deployment of on-board safety technologies. As the market matures, leveling the competitive playing field, this may become less significant as a decision factor.

- Driver Acceptance is considered important by a number of carriers. Drivers were receptive to on-board safety technologies, as long as the devices are proven effective in improving safety, are user friendly, and that the recorded data will not be used to violate their privacy.

- In-cab Technology Interface Integration is an important factor to a number of the stakeholders interviewed. This factor plays a key role in enabling the various stakeholders to realize the value of on-board safety technologies with minimum cost, distraction, and potential for errors.

Figure 1 shows what factors affect different stakeholder groups. The four factors shown in bold are deemed to be most important and are connected to the stakeholders. It should be mentioned that the ten factors listed are considered important based on the interviews, workshop, and other feedback received during the course of the project, including that from ATRI. The higher priority factors were selected based on their importance to the purchase decision maker (the 
motor carrier) and the extent to which each factor is pervasive or important to a broad crosssection of stakeholders. For example, ROI is a factor unique to carriers, but almost all carriers emphasized its importance in their deciding to adopt on-board safety technology. Proof of effectiveness is pervasive and was mentioned by all stakeholder groups and most stakeholders surveyed as important. Likewise, reliability and maintainability along with liability concerns were pervasive factors and were mentioned by many of the stakeholders surveyed in the interviews and the workshop.

Table 2 lists the factors and includes selected comments of the different stakeholders interviewed as extracted from the interview survey and expert panel. The following sections address these factors from the perspectives of the stakeholders interviewed, which include motor carriers, drivers, independent owner-operators, vehicle manufacturers, device manufacturers, and insurance companies.

\subsection{Stakeholder Findings}

The following sections summarize the responses from the stakeholders interviewed in this task. The Expert Panel Workshop, summarized in Appendix D, provides supporting information for these findings.

\subsubsection{Motor Carriers' Perspective}

Figure 2 illustrates how the motor carriers interviewed responded to a series of issues posed to them in the interviews. The motor carriers were asked to give a numerical ranking expressing their opinion on the priority each issue played in their purchase-decision process ( 1 for low and 5 for high). The numerical score for each issue represents the number of carriers times the priority placed by each on that issue.

The three most important issues for those motor carriers interviewed are accuracy and reliability of the system, cost to install and maintain the technology, and proven effectiveness of the technology to improve safety. Two high ranked issues relate to driver acceptance and satisfaction. The numerical ranking assigned by the carriers determined the level of importance. 


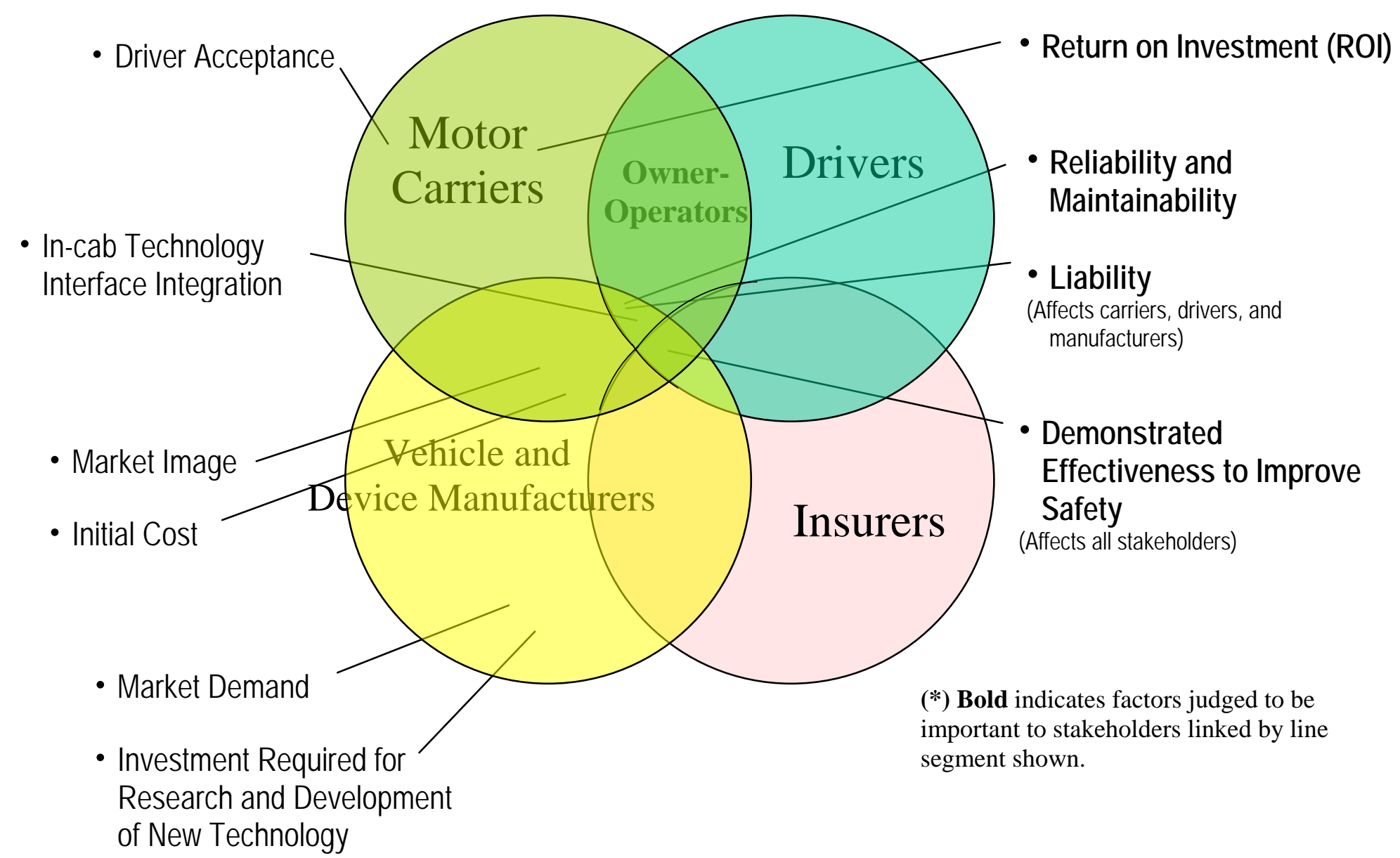

Figure 1. Factors that Influence Stakeholder Decision Making 
Table 2. Factors for Stakeholder Decision Making

\begin{tabular}{|c|c|c|c|c|c|c|}
\hline \multirow[b]{2}{*}{ FACTOR } & \multicolumn{6}{|c|}{ Stakeholder Survey Group Comments } \\
\hline & Motor Carriers & $\begin{array}{c}\text { Vehicle } \\
\text { Manufacturers } \\
\text { (OEMs) }\end{array}$ & $\begin{array}{c}\text { Device } \\
\text { Manufacturers }\end{array}$ & $\begin{array}{c}\text { Independent } \\
\text { Owner-Operators }\end{array}$ & Company Drivers & Insurers \\
\hline $\begin{array}{l}\text { Return on Investment } \\
\text { for Purchaser }\end{array}$ & $\begin{array}{l}\text { Carriers' profit margins are } \\
\text { small. A positive ROI is } \\
\text { essential with a 12- to 18- } \\
\text { month payback. }\end{array}$ & & & & $\begin{array}{l}\text { Drivers recognize that } \\
\text { profitability means job } \\
\text { security. If improvement of } \\
\text { operations can be realized } \\
\text { through the introduction of } \\
\text { on-board safety } \\
\text { technologies, drivers said } \\
\text { they would be more likely to } \\
\text { support its use. }\end{array}$ & \\
\hline $\begin{array}{l}\text { Demonstrated } \\
\text { Effectiveness to } \\
\text { Improve Safety }\end{array}$ & $\begin{array}{l}\text { Carriers are concerned } \\
\text { about safety and security of } \\
\text { drivers, cargo, and } \\
\text { equipment (vehicles). }\end{array}$ & $\begin{array}{l}\text { All OEMs recognize that it is } \\
\text { important (mandatory) to } \\
\text { produce safe vehicles } \\
\text { because safety influences } \\
\text { sales. } \\
\text { Safety and security can be } \\
\text { differentiators resulting in } \\
\text { people buying their tractors. } \\
\text { Lack of safety can be an } \\
\text { expensive liability in crash } \\
\text { analysis and assignment of } \\
\text { responsibility. }\end{array}$ & & $\begin{array}{l}\text { Operators realize that they } \\
\text { will benefit from improved } \\
\text { safety and security in the } \\
\text { trucks. } \\
\text { Independent owner- } \\
\text { operators face enforcement } \\
\text { action and fines. Also, } \\
\text { clients will not hire them if } \\
\text { they have a poor safety } \\
\text { record. Anything that can } \\
\text { help them avoid crashes is } \\
\text { of interest. As with } \\
\text { company drivers, they are } \\
\text { concerned about privacy } \\
\text { issues and do not want on- } \\
\text { board safety technologies to } \\
\text { take control of their vehicles. }\end{array}$ & $\begin{array}{l}\text { Drivers realize that they will } \\
\text { be the people that directly } \\
\text { benefit from improved safety } \\
\text { and security in the trucks. } \\
\text { In addition, drivers } \\
\text { sometimes face penalties } \\
\text { and even job loss for } \\
\text { crashes. Drivers support } \\
\text { anything that can help them } \\
\text { avoid crashes as long as } \\
\text { control and privacy are not } \\
\text { violated. }\end{array}$ & $\begin{array}{l}\text { Insurance reductions for use } \\
\text { of on-board safety } \\
\text { technologies will be } \\
\text { considered only when } \\
\text { proven crash reductions are } \\
\text { established. Reduction in } \\
\text { crash severity also would be } \\
\text { considered in establishing } \\
\text { rates if good data were } \\
\text { available. }\end{array}$ \\
\hline
\end{tabular}


Table 2. Factors for Stakeholder Decision Making (continued)

\begin{tabular}{|c|c|c|c|c|c|c|}
\hline \multirow[b]{2}{*}{ FACTOR } & \multicolumn{6}{|c|}{ Stakeholder Survey Group Comments } \\
\hline & Motor Carriers & $\begin{array}{c}\text { Vehicle } \\
\text { Manufacturers } \\
\text { (OEMs) }\end{array}$ & $\begin{array}{c}\text { Device } \\
\text { Manufacturers }\end{array}$ & $\begin{array}{c}\text { Independent } \\
\text { Owner-Operators }\end{array}$ & Company Drivers & Insurers \\
\hline $\begin{array}{l}\text { Reliability and } \\
\text { Maintainability }\end{array}$ & $\begin{array}{l}\text { On-board safety } \\
\text { technologies must be easy } \\
\text { to use, provide accurate } \\
\text { results, be consistently } \\
\text { reliable, and be easy to } \\
\text { maintain. Any } \\
\text { inconsistencies or high } \\
\text { maintenance requirements } \\
\text { will discourage purchase by } \\
\text { carriers. }\end{array}$ & $\begin{array}{l}\text { Unreliable products can } \\
\text { result in warranty claims } \\
\text { translating to cost and } \\
\text { increased liability. An OEM } \\
\text { must produce a product with } \\
\text { a long life ( } 5 \text { to } 10 \text { years). } \\
\text { Therefore, most items will } \\
\text { need some level of } \\
\text { maintenance in the field. } \\
\text { OEMs are sensitive to the } \\
\text { complexity of systems and } \\
\text { the ability to maintain } \\
\text { systems by their customers } \\
\text { and associated repair } \\
\text { centers. The skill level } \\
\text { required to provide repair } \\
\text { services can be a limiting } \\
\text { obstacle for on-board safety } \\
\text { technologies. }\end{array}$ & & $\begin{array}{l}\text { Independent owner- } \\
\text { operators are aware of the } \\
\text { concept of "false positives". } \\
\text { On-board safety } \\
\text { technologies must provide } \\
\text { accurate, consistent, and } \\
\text { reliable information to the } \\
\text { driver. They must be } \\
\text { convinced that intervention } \\
\text { to control the vehicle is safe } \\
\text { and beneficial. } \\
\text { Owner-operators are } \\
\text { interested only in equipment } \\
\text { that is reliable. An } \\
\text { excessive need for } \\
\text { maintenance is a deterrent } \\
\text { to on-board safety } \\
\text { technology. }\end{array}$ & $\begin{array}{l}\text { Drivers are aware of the } \\
\text { concept of "false positives". } \\
\text { On-board safety } \\
\text { technologies must provide } \\
\text { accurate and reliable } \\
\text { information to the driver. } \\
\text { Drivers recognize that any } \\
\text { system they rely on must be } \\
\text { accurate and dependable or } \\
\text { it presents a potential safety } \\
\text { issue. } \\
\text { Drivers must be convinced } \\
\text { that any intervention to } \\
\text { control the vehicle is safe } \\
\text { and beneficial. }\end{array}$ & \\
\hline Liability & $\begin{array}{l}\text { If carriers installed on-board } \\
\text { safety technologies and } \\
\text { drivers did not use them, } \\
\text { crash liabilities could be } \\
\text { assessed to the carrier. } \\
\text { At the expert panel on } \\
\text { August } 7,2003 \text {, carriers felt } \\
\text { that the monitoring aspects } \\
\text { of on-board safety } \\
\text { technologies could be } \\
\text { beneficial if used for reward. }\end{array}$ & $\begin{array}{l}\text { There is a concern that } \\
\text { failure of on-board safety } \\
\text { technologies to perform as } \\
\text { expected could place liability } \\
\text { on the OEM and other } \\
\text { component manufacturers. }\end{array}$ & $\begin{array}{l}\text { Vendors are aware of } \\
\text { liability issues. The } \\
\text { perception of increased } \\
\text { liability will have an impact } \\
\text { on the decision to } \\
\text { manufacture it. }\end{array}$ & $\begin{array}{l}\text { Owner-operators expressed } \\
\text { concerns that the data } \\
\text { collected by on-board safety } \\
\text { technologies could be used } \\
\text { against them in crash } \\
\text { investigations. They do not } \\
\text { like the idea of being } \\
\text { monitored while they drive. }\end{array}$ & $\begin{array}{l}\text { Drivers expressed concerns } \\
\text { that the data collected by } \\
\text { on-board safety } \\
\text { technologies could be used } \\
\text { against them in crash } \\
\text { investigations. They do not } \\
\text { like the idea of being } \\
\text { monitored while they drive. }\end{array}$ & \\
\hline Market Demand & & $\begin{array}{l}\text { If buyers are asking for on- } \\
\text { board safety technologies, } \\
\text { the OEM is more likely to } \\
\text { make it as either standard or } \\
\text { optional equipment. }\end{array}$ & $\begin{array}{l}\text { If buyers are asking for on- } \\
\text { board safety technologies, } \\
\text { vendors are more likely to } \\
\text { offer it to both OEMs and } \\
\text { aftermarket suppliers. }\end{array}$ & & & \\
\hline
\end{tabular}


Table 2. Factors for Stakeholder Decision Making (continued)

\begin{tabular}{|c|c|c|c|c|c|c|}
\hline \multirow[b]{2}{*}{ FACTOR } & \multicolumn{6}{|c|}{ Stakeholder Survey Group Comments } \\
\hline & Motor Carriers & $\begin{array}{c}\text { Vehicle } \\
\text { Manufacturers } \\
\text { (OEMs) }\end{array}$ & $\begin{array}{c}\text { Device } \\
\text { Manufacturers }\end{array}$ & $\begin{array}{c}\text { Independent } \\
\text { Owner-Operators }\end{array}$ & Company Drivers & Insurers \\
\hline Initial Cost & $\begin{array}{l}\text { Although carriers may } \\
\text { recognize the benefits of the } \\
\text { technology and fully } \\
\text { appreciate the cost-benefit } \\
\text { analysis, they may not have } \\
\text { the available capital to } \\
\text { purchase equipment. } \\
\text { Some carriers surveyed } \\
\text { mentioned a range of } \\
\$ 1,000 \text { to } \$ 1,500 \text { as the } \\
\text { maximum allowable initial } \\
\text { cost for an individual on- } \\
\text { board safety system, such } \\
\text { as RA\&C. }\end{array}$ & $\begin{array}{l}\text { OEMs must be able to } \\
\text { supply equipment that is } \\
\text { affordable to their clients. } \\
\text { Several OEMs felt that an } \\
\text { initial cost of about } \$ 1,000 \\
\text { or less would be needed to } \\
\text { penetrate the carrier market. } \\
\text { This is consistent with } \\
\text { comments from some of the } \\
\text { carriers. }\end{array}$ & $\begin{array}{l}\text { Because costs are important } \\
\text { to vendors, they must be } \\
\text { able to supply equipment } \\
\text { that is affordable to their } \\
\text { clients. }\end{array}$ & $\begin{array}{l}\text { Independent owner- } \\
\text { operators pay for the } \\
\text { equipment put into their } \\
\text { cabs. Cost is clearly a } \\
\text { decision factor for procuring } \\
\text { in-cab safety equipment. }\end{array}$ & & \\
\hline $\begin{array}{l}\text { Investment Required } \\
\text { for Research and } \\
\text { Development of New } \\
\text { Technology }\end{array}$ & & $\begin{array}{l}\text { Both development and } \\
\text { production costs are } \\
\text { important to OEMs. High } \\
\text { development costs can } \\
\text { discourage investments. } \\
\text { Research investments can } \\
\text { be risky because of the } \\
\text { many unknowns inherent } \\
\text { with new developments. An } \\
\text { investment in something } \\
\text { new always has a chance of } \\
\text { failure resulting in sunk } \\
\text { costs that can be } \\
\text { substantial. }\end{array}$ & $\begin{array}{l}\text { Research, development, } \\
\text { and production costs can be } \\
\text { prohibitive when designing } \\
\text { and producing products with } \\
\text { rapidly changing } \\
\text { technologies. }\end{array}$ & & & \\
\hline Market Image & $\begin{array}{l}\text { Carriers compete for } \\
\text { customers. Their image or } \\
\text { reputation in the business is } \\
\text { important to them. Running } \\
\text { a state-of-the-art fleet that } \\
\text { operates safely and } \\
\text { efficiently is important to } \\
\text { carriers' marketing } \\
\text { programs. Crashes cause } \\
\text { delays, additional costs, and } \\
\text { damaged cargos. }\end{array}$ & $\begin{array}{l}\text { OEMs recognize the } \\
\text { importance of their image in } \\
\text { the market place. Image is } \\
\text { earned but also influenced } \\
\text { by progressiveness to } \\
\text { maintain leadership in } \\
\text { offering the best quality and } \\
\text { features. OEMs know that } \\
\text { the proper use of new } \\
\text { technology is key to } \\
\text { maintaining a competitive } \\
\text { edge. }\end{array}$ & & $\begin{array}{l}\text { If the clients that hire the } \\
\text { independent owner- } \\
\text { operators think that use of } \\
\text { on-board safety } \\
\text { technologies is important, it } \\
\text { may influence whom they } \\
\text { hire. If the independent } \\
\text { driver thinks that on-board } \\
\text { safety technologies can } \\
\text { positively influence their } \\
\text { client business, they will be } \\
\text { more interested in making } \\
\text { the investment. }\end{array}$ & & $\begin{array}{l}\text { Insurance companies are } \\
\text { concerned about their } \\
\text { image, so they want their } \\
\text { clients to think they are } \\
\text { getting the best rates. } \\
\text { Clients like to receive credits } \\
\text { for their investments. It } \\
\text { makes them feel that their } \\
\text { insurance company is trying } \\
\text { to help them in every way } \\
\text { they can. }\end{array}$ \\
\hline
\end{tabular}


Table 2. Factors for Stakeholder Decision Making (continued)

\begin{tabular}{|c|c|c|c|c|c|c|}
\hline \multirow[b]{2}{*}{ FACTOR } & \multicolumn{6}{|c|}{ Stakeholder Survey Group Comments } \\
\hline & Motor Carriers & $\begin{array}{c}\text { Vehicle } \\
\text { Manufacturers } \\
\text { (OEMs) }\end{array}$ & $\begin{array}{c}\text { Device } \\
\text { Manufacturers }\end{array}$ & $\begin{array}{c}\text { Independent } \\
\text { Owner-Operators }\end{array}$ & Company Drivers & Insurers \\
\hline Driver Acceptance & $\begin{array}{l}\text { Carriers are sensitive to } \\
\text { drivers' attitudes and } \\
\text { opinions, and recognize the } \\
\text { importance of providing } \\
\text { good equipment and } \\
\text { maintaining a safe operating } \\
\text { environment to retain a } \\
\text { qualified driver team. }\end{array}$ & & & $\begin{array}{l}\text { Any on-board safety } \\
\text { technology must be easy to } \\
\text { use. Owner-operators are } \\
\text { not interested in using } \\
\text { systems that are complex, } \\
\text { hard to use, or require } \\
\text { extensive training; the } \\
\text { systems should be able to } \\
\text { be self-taught (training for } \\
\text { an independent operator is } \\
\text { usually uncompensated } \\
\text { time). }\end{array}$ & $\begin{array}{l}\text { Any on-board safety } \\
\text { technology must be easy to } \\
\text { use, consistent in how it } \\
\text { works for various vendors } \\
\text { and vehicles, and not } \\
\text { require extensive training. } \\
\text { Generally the reaction from } \\
\text { drivers was positive in the } \\
\text { interviews. Drivers at the } \\
\text { Expert Panel meeting had a } \\
\text { positive reaction to RA\&C. } \\
\text { They stated that they would } \\
\text { welcome training and the } \\
\text { chance to have this } \\
\text { technology in their vehicles. } \\
\text { Also, the reaction from } \\
\text { drivers in the FOT was } \\
\text { positive relating to this } \\
\text { system. }\end{array}$ & \\
\hline $\begin{array}{l}\text { In-cab Technology } \\
\text { Interface Integration }\end{array}$ & & $\begin{array}{l}\text { Any new technologies must } \\
\text { be compatible and } \\
\text { interoperable with existing } \\
\text { system designs. OEMs } \\
\text { stated that a good } \\
\text { technology could be omitted } \\
\text { if it conflicts with existing } \\
\text { systems thought to be } \\
\text { essential. For example, a } \\
\text { device may not be } \\
\text { compatible with the human } \\
\text { interfaces currently in the } \\
\text { cab. }\end{array}$ & & $\begin{array}{l}\text { The amount of equipment in } \\
\text { a commercial vehicle cab } \\
\text { continues to increase. The } \\
\text { systems must integrate to } \\
\text { what is there and not } \\
\text { interfere with driver primary } \\
\text { responsibilities. }\end{array}$ & $\begin{array}{l}\text { The amount of equipment in } \\
\text { a commercial vehicle cab } \\
\text { continues to increase. If the } \\
\text { on-board safety technology } \\
\text { distracts the driver in any } \\
\text { way, the driver will often } \\
\text { react by taking measures to } \\
\text { sabotage or turn the unit off. } \\
\text { The systems must integrate } \\
\text { with what is there and not } \\
\text { interfere with driver primary } \\
\text { responsibilities. }\end{array}$ & \\
\hline
\end{tabular}




\section{Issue}

Accuracy and reliability of the system

Cost to install and maintain

Effectiveness of the system to improve safety

Overall driver satisfaction. Reduced turnover

Reduced accident related costs

Driver acceptance of system

Insurance company requirement

$\operatorname{Tax}$

Reduced insurance premiums

Cost to train drivers

Federal requirement

Good corporate citizen

0

5

Number of respondents times rating of 1 to 5

Figure 2. Carrier Survey Results 
The motor carrier industry faces ongoing public scrutiny and government certification requirements while struggling to maintain a positive image in the highly competitive and complex logistics environment. In the context of this section, "government certification requirements" include state fuel tax stickers, trip permits, hazmat certification (depending on the load), commercial driver licensure, vehicle inspection (CVSA stickers to avoid weigh station delays), State-Federal DOT inspections by the North American Vehicle Inspection Standard, registration, insurance, ton mileage tax plates (TMT plates), DOT registration, and pre-pass certification. As a result, they are motivated to invest in products that are proven, affordable, and provide a reasonable return on investment. Nevertheless, technology has been the impetus behind many changes for motor carriers. Bar coding, material-handling systems, mobile communications and tracking technologies, carrier-routing programs, and electronic commerce have enabled shippers/consignees and carriers to realize improved operating efficiencies through enhanced resource utilization. The motor carriers interviewed also recognize the potential of technology to improve safety.

Initial introduction of technology may offer market differentiation for the carrier, but, later in the lifecycle, it may become a competitive necessity. Today, using on-board safety technologies can improve a carrier's image by marking the company as progressive and concerned about the safety and security of their drivers and loads according to the interviews.

\section{Reliability and Maintainability}

The carriers interviewed view on-board safety technologies as complex electronic computer systems that must be integrated into their cabs. There is concern that the cost to ensure proper operation (i.e., maintenance and calibration) and repair will be high. Cost concerns include the down time of the tractors while repairs are done. These carriers also expressed concern about the added cost to ensure that personnel have the skills required to maintain on-board safety devices.

Several carriers mentioned that they are apprehensive about the possibility of the technology indicating false positives ${ }^{8}$, which may lead to drivers learning to ignore the warning device. The technology must be easy to use, provide accurate results, and must be easy to maintain. Fear of inconsistent or unreliable data from improperly operating equipment may have negative effects. This apprehension causes concern about carrier liability if systems do not operate effectively. The interviewed carriers were concerned if they could be held liable in cases in which crashes occurred that should have been mitigated by the on-board safety device.

The carriers interviewed also were concerned about the systems' ability to operate in all driving conditions. An example cited was the effectiveness of LDW when roads are covered with snow or in construction zones. The vendor who makes the RA\&C specifies that the system is less effective on wet, snowy, and icy roadways.

\section{Demonstrated Effectiveness to Improve Safety}

Carriers acknowledged that effectiveness is the key to acceptance. "Effectiveness of the system is the only reason to do it," one carrier said. "If the system works, tax breaks won’t be the key

\footnotetext{
${ }^{8}$ False positives are cases where the on-board safety device indicates a warning when none should occur.
} 
issue.” Although carriers indicated the need for proof of effectiveness in improving safety, a few respondents were skeptical of test data, especially manufacturer assertions and new technology claims. They indicated that test situations often do not accurately mirror actual operating conditions. Carriers expressed concern that should on-board safety technology be found effective in reducing large truck crashes, the USDOT might impose regulations requiring its use. Unanimously, they felt that the installation of on-board safety technologies should not be regulated, but should be a business decision made by the private sector.

The carriers voiced concerns about on-board safety technologies causing driver distraction that reduces rather than improves safety. Carriers also were concerned that drivers might become too dependent on the on-board safety technology. One carrier's safety director, interviewed as part of the interview survey, pointed out that the company "could not subscribe to technology that takes the driver out of driving." He cited cruise control as an example that led to increased crashes because drivers were not paying as much attention.

Several carriers discussed the Eaton VORAD collision-warning radar system, which is one of the more recognized on-board safety technologies in the industry. One carrier who installed the Eaton VORAD system on approximately 90 percent of its fleet acknowledged a dramatic reduction in both the severity and frequency of crashes. This carrier reported only two lanechange crashes in approximately 150 million vehicle-miles-traveled and significantly less severe rear-end crashes. Another carrier indicated that it was considering pilot testing the Eaton VORAD system. The respondent thought "that it would reinforce or modify driving behavior and they might use it in their training program." This same respondent also pointed out that the company had seen a " 25 percent reduction in backing accidents since installing video cameras, but we also simultaneously instituted a driver-training program emphasizing this type of accident.”

Carrier interviews revealed a true interest by interviewed stakeholders in safety that extended beyond a pure monetary benefit. However, they also revealed a reluctance to accept claimed safety benefits without concrete evidence of effectiveness. The required investment needed for deployment can be substantial, and investments are highly scrutinized by carriers due to the competitive environment in which they operate and the low profit margins of the industry.

\section{Driver Acceptance}

Ensuring driver acceptance is an important decision-making factor for motor carriers when purchasing on-board safety technologies. Carriers recognize that good drivers like to work for companies that are concerned about their safety and are willing to invest in technology that helps them perform their job better. Carriers understand that they can attract and retain good drivers by showing a sincere commitment to safety and security in their operations. One carrier suggested that on-board safety technology would be more effective if it were used for positive as well as negative feedback from drivers. 


\section{Initial Cost}

Many of the respondents hesitated to identify an acceptable maximum initial cost. Those who did respond indicate $\$ 1,000$ to $\$ 1,500$ per technology (e.g., the RA\&C) to be a reasonable cost range. Motor carriers also cited ceilings on debt ratios that dictate how much can be purchased independent of availability and benefits. One interviewed company representative stated that "We have 1,100 trucks and at $\$ 1,000$ per truck that is $\$ 1.1$ million. We need to know that we will be saving $\$ 1$ million or more. Show me a financial offset to justify the input of costs up front."

\section{Return on Investment for Purchaser}

Motor carriers are concerned about the potential return on investment for on-board safety technologies. They want quantifiable data on costs and benefits. One interviewed carrier presented the following scenario: To install an $\$ 800$ item into a fleet of 3,000 vehicles, costing \$2.4 million, requires break-even payback in six to eight months; there must be ongoing payback. Other carriers stated that they looked for payback in the 12- to 18-month timeframe. None indicated a payback greater than 24 months as being acceptable.

The interviewed motor carriers also mentioned that some on-board safety technologies require interfaces to the transportation infrastructure. For example, some LDW systems look for a pattern of line striping on the highway to determine lane position. Likewise, some in-cab signing may require roadside-to-vehicle communications to pass safety information to the drivers. Therefore, additional investment will be required to maintain the infrastructure of on-board safety technologies.

Every carrier interviewed stated that cost savings is a priority, but they also expressed a concern for the safety of their drivers. This illustrates that indirect benefits, such as avoiding loss of life or impairment, are also important to carriers. With that in mind, carriers expressed interest in technology that addresses security and safety of the driver, cargo, and equipment.

Motor carriers also mentioned the cost and benefit of competing ways to improve safety such as safety awareness and training. Historically, these techniques have offered the motor carrier benefits that are more tangible, familiar, and historically effective. Creating safety awareness and offering driver training always will be part of the operational activities of carriers, but it could be complemented with on-board safety technologies for increased benefits. One of the interviewed carriers indicated "accident costs are low, which makes it hard to justify spending for technology when we don't have problems. It's hard to get management to spend extra money for new systems when we are doing well without it." While carriers are somewhat aware of invehicle safety technologies, interview data show that most (77 percent) are not using them. As a result, a reduction in number or severity of crashes due to technology intervention may not be recognized or easy for carriers to quantify. Thus, information on the costs and benefits of onboard safety technology must be relayed to carriers. 


\subsubsection{Drivers' Perspective}

Twenty drivers were interviewed from a set of questions focusing on drivers' experiences and opinions about on-board safety technologies. The drivers were asked to comment on their familiarity with safety systems and any training they might have received. Of the 20 drivers interviewed, 14 drivers did not use on-board safety technology, and only a few were really aware of on-board safety technologies. Many of these drivers had difficulty answering survey questions, since they had limited knowledge and experience using the systems. Yet, the majority of these drivers expressed a willingness to try the systems. Also, the drivers at the Expert Panel meeting expressed a positive attitude toward gaining additional knowledge and using on-board safety technologies.

The majority of the drivers were familiar with ABS technology, but most had little to no familiarity with ECBS, GPS, LDW, RA\&C, CWS/ACC, or side-looking radar. The interviews were conducted informally at roadside truckstops and at driver-training sessions. The drivers were given a series of statements about truck safety systems and asked to indicate their level of agreement or disagreement with the statements.

Figure 3 shows the response of drivers to those questions on a scale of -2 to +2 , with -2 being strong disagreement and +2 being strong agreement. The numerical score in Figure 3 is the number of drivers times their respective level of agreement or disagreement.

The interview sample included several independent owner-operators as well as carrier-employed drivers. ${ }^{9}$ Although the independent owner-operators and carrier-employed drivers had much in common, the independent owner-operators expressed decision-making criteria that differ from carrier-employed drivers. These differences are motivated primarily by the availability of investment dollars and capital funds. Therefore, the analysis of independent owner-operators is presented separately in the next section. This section addresses the responses of carrieremployed drivers.

\section{Reliability and Maintainability}

One important factor that emerges from these questions is the lack of trust in the reliability of onboard safety technology to improve safety. Drivers strongly disagreed that the technology would be inherently reliable and accurate. Self-diagnostics that detect on-board safety technology operational problems and immediately inform the driver is a desirable feature for any equipment. Also, the drivers indicated that a procedure should be developed to allow them to formally report suspected system problems.

\section{Driver Acceptance}

On other questions, the driver responses indicate that they are receptive to on-board safety technology. No other major concerns were cited based on this series of questions. All expressed

\footnotetext{
${ }^{9}$ Independent owner-operators own and drive their own tractors. A carrier-employed driver is employed by a specific carrier or company to drive company-owned vehicles.
} 


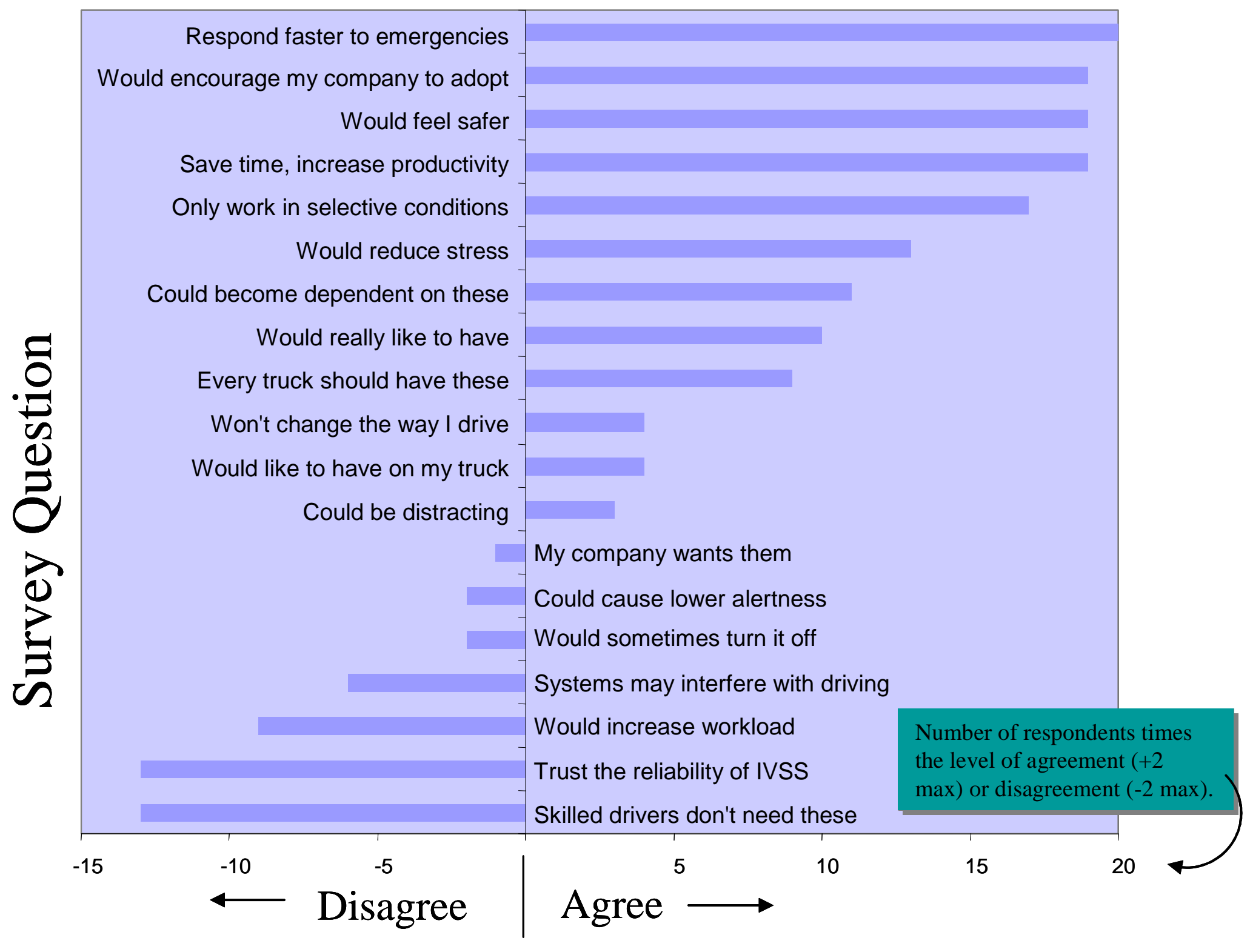

Figure 3. Driver Attitudes Regarding the Use of On-board Safety Systems in General on Commercial Vehicles 
a willingness to use on-board safety technology if their carrier decided to adopt it. Many company drivers have strong opinions about the technologies, but they recognize that they are captive to their carrier companies and drive trucks that the carrier owns.

Carrier-employed drivers recognize that their willingness to use on-board safety technologies is important to the carriers. The cost of a single crash can be significant to a carrier. More than 80 percent of carriers have fewer than 20 tractors, and a single crash can put a small carrier out of business. ${ }^{10}$ On the other hand, a reduction in crash rate contributes to the success and growth of a carrier. Drivers want the organizations for which they work to succeed because they understand that their employment longevity and quality of work life depend on it.

The drivers interviewed indicated that on-board safety technologies must be easily understood and not require extensive training for proper use. Time taken for training is time that the trucks are not operating and making money for the carrier and the driver. However, the drivers would like to be paid for driver training; they resent sitting in training sessions on their own time.

The drivers uniformly rejected any government mandates imposed on the industry. They want to use an on-board safety technology only if it helps them do their job.

\section{In-cab Technology Interface Integration/Demonstrated Effectiveness to Improve Safety}

Drivers expressed interest in their personal safety and security. The interviews revealed willingness and even a desire to obtain access to systems that would improve safety and security. Drivers look for systems that are easy to use and not distracting. Drivers did not feel that the technology would distract them unless it was noisy or visually disruptive (e.g., bright flashing warning lights). They were skeptical of annoying alerts, and voiced concerns about being unable to lower a sound volume that might disturb a sleeping co-driver. Nearly one-third of the drivers liked the SmartCruise CWS/ACC concept because it would make driving safer, ensuring safe following distances without the driver having to adjust cruise control in response to surrounding traffic or having to guess the speed of the leading vehicle. In addition, any indication that onboard safety devices might take control of the vehicle (i.e., automated braking) was met with resistance. Interviews with drivers showed that they want to retain full control of their vehicles, an attitude that was expressed by one of the interviewed carriers as evident in the introduction of other on-board technology (e.g., cruise control).

\section{Liability}

Most drivers were aware that some on-board safety technologies collect and retain data that could be used to evaluate driver performance. Some were concerned that on-board safety technology would allow invasion of personal privacy and have an impact on performance reviews. The drivers were concerned about how the technology might be used to punish them. While drivers did not wish to conceal their driving behavior, they did not want it recorded and used against them.

\footnotetext{
10“Active Carriers by Fleet Size with Percentages - All Active Carriers,” Office of Motor Carriers Management Information System, Special Report LS50B901, March 4, 2002.
} 
According to ATRI, the courts have generally held to date that truck drivers, by virtue of their use of the public highways, have a lesser expectation of privacy. ${ }^{11}$ However, as technology evolves, and more and more data are collected, a driver's expectation of privacy may be more widely recognized, raising constitutional questions. Therefore, proper regulation of the use and dissemination of data collected by on-board technologies becomes ever more important to ensure a level of privacy that is acceptable to the drivers.

\subsubsection{Independent Owner-Operators' Perspective}

The Owner-Operator Independent Drivers Association (OOIDA) describes its typical member as an over-the-road truck driver in his/her mid- to late 40s with nearly 20 years of experience. The interviewed independent owner-operators indicated general familiarity with the concept of onboard safety technology, but they were not aware of specific projects or performance details. Many had heard of Eaton VORAD, but advanced on-board safety technology, such as RA\&C, was not familiar to them. The independent owner-operators shared the company drivers' concerns about the potential use of the technology for other than safety warnings. They voiced concern that on-board safety devices — an unfamiliar technology to them-would be a sort of "big brother" observer capable of recording information about their driving decisions and behaviors. They did not welcome this prospect, particularly if the information became public. ${ }^{12}$

\subsubsection{Vehicle Manufacturers' Perspective}

The vehicle original equipment manufacturer (OEM) designs and builds the tractors. The OEMs decide the standard equipment or options that are available in the cab, including any on-board safety technology. One OEM interviewed mentioned that it typically takes a new technology over 4 years to go from being an option to becoming standard equipment.

Often the OEM purchases the equipment from a supplier (vendor) and integrates it into the tractor. Occasionally, the OEM designs and manufactures the in-cab equipment. The RA\&C is an example of an OEM designing one element (the roll stability advisor) and the vendor adding another, the roll stability controller.

The OEMs are aware of many of the on-board safety technologies, such as the Eaton VORAD system (CWS/ACC). They were less familiar with the RA\&C, with the exception of Freightliner, which is working closely with Meritor WABCO on the RA\&C FOT.

As explained in Appendix B, the interviews with the OEMs did not follow the formal interview guidelines as did those with carriers and drivers. As a result, OEM interview results are more qualitative and do not support quantitative analysis. In general, the OEMs are motivated to build what their customers will buy. They currently are undergoing severe economic stress due to a

\footnotetext{
${ }^{11}$ American Transportation Research Institute, "Regulatory and Legal Issues Potentially Impacting the Development and Deployment of On-board Safety Technology Systems,” Technical Memorandum to Battelle, April 2003.

12،"Technical Memorandum: Issues Associated with the Utilization of On-board Safety Systems," Submitted by the ATA Foundation, 2002.
} 
dramatic slowing of sales of new trucks and an abundance of used trucks on the market. ${ }^{13}$ Consequently, OEMs are reducing staff and deep-discounting truck prices. Therefore, only equipment that is cost effective and in demand by customers is offered.

\section{Market Demand}

OEMs also said they were driven by the competitive market to maintain the "cutting-edge" in their products. Thus, they are motivated to offer on-board safety technology to maintain the image they seek in the marketplace. OEMs said they were constantly looking for market differentiators that encourage the truck buyers to select their products. Nevertheless, these systems are often offered as options rather than as standard equipment. Another interviewed OEM described the market as a "pull-market" (i.e., if the customer wants something, the manufacturers will respond). OEMs see the carrier as the chief driving force in the Class 7 and 8 truck market in that every truck is usually custom designed despite manufacturers' efforts at standardization.

One OEM interviewed stated that larger carriers would be more likely to adopt on-board safety technology because of their greater capital availability. However, another OEM thought that larger carriers might not see the benefit of adopting on-board safety technology because of the high cost of equipping a large fleet, whereas small carriers could afford to equip their fleet and even one accident might impact them substantially.

Several OEMs described purchase behavior in European and Australian markets as OEM driven. The European OEMs determine the options to put in the cab and the carriers accept it as a package. They said that developing and selling new cost-effective products and introducing new technologies are more difficult in the United States than in Europe.

However, as one interviewed manufacturer indicated, if the technology can show a financial benefit, the market demand rate increases. They cited the example of electronic ignition, which yielded six percent greater fuel economy than mechanical ignition. Mechanical ignition disappeared rapidly after this became evident.

In the absence of clear benefits-cost data, cost-containment drives acceptance unless "add-on" safety features are mandated. One manufacturer prepares cabs with the VORAD system, but few have been requested. Another manufacturer cited a safety feature in its cab, a special seat for rollover protection, which has not sold well.

ABS is another example of a technology introduced into the vehicles. The manufacturer that cited this example standardized its vehicles with ABS before the technology was mandated. ${ }^{14}$ Although they could show better braking, it was still not well accepted-only about 15 to 20 percent of the vehicles were purchased before the mandate. Moreover, as this manufacturer

\footnotetext{
${ }^{13}$ The industry is also concerned about how government will use the data collected. ATA Foundation, "Technical Memorandum: Issues Associated with the Utilization of On-board Safety Systems,” 2002.

${ }^{14}$ Federal Motor Vehicle Safety Standard (FMVSS) 121 requires ABS on truck tractors manufactured after March 1 , 1997 and other air-braked vehicles after March 1, 1998 http://www.nhtsa.dot.gov/cars/rules/regrev/evaluate/EP/HTABS.html.
} 
pointed out, it was easier to demonstrate benefits of ABS than other safety technologies because truck operators can easily relate to braking issues.

\section{Initial Cost}

The most important factor expressed by OEMs is that new technology must not reduce profitability and must be affordable by the customer. Every OEM interviewed is concerned with the initial cost of their products.

\section{Return on Investment for Purchaser}

OEMs and their customers (carriers and independent owner-operators) operate in a very competitive, financially conservative business. OEMs recognize that their customers are reluctant to buy unless there is a payback. One OEM sees the industry as highly diverse and indicated that willingness for his customer to pay for on-board safety technology is a function of how soon it will provide a return. However, according to the survey of OEMs, their customers, again, need to see savings in terms of a reduction in crashes and insurance premiums.

\section{Demonstrated Effectiveness to Improve Safety}

Each OEM interviewed said that safety and security are primary priorities. Lack of safety can be an expensive liability in crash analysis. The OEMs realize that unsafe products jeopardize future business and can lead to liability issues. An excellent safety record and use of associated safety devices are product differentiators. The OEMs feel that buyers (carriers) value safety performance and equipment in their purchasing decisions.

Manufacturers also are concerned about driver attitudes toward on-board safety technology. They are not certain that drivers are willing to give up control of the vehicle or that they will be comfortable with on-board safety technology. Drivers ultimately are the end users of the devices.

Buyers of trucks recognize the importance of drivers in achieving safety benefits. Therefore, drivers are providing input to the purchasing department on purchasing decisions. Also, one OEM interviewed indicated that if the driver believes the on-board safety technology is not functioning properly or is distracting, they will find a way to turn the systems off. However, one interviewed carrier stated that drivers that attempt to disable an on-board safety technology would be terminated. Drivers interviewed stated that they would like to have the option to disable the system.

\section{Liability}

The OEMs consistently expressed concerns about the liabilities posed by on-board safety technology. Although they want to offer the technology if it is proven to improve safety, they want assurance about the level of liability they face if one of their vehicles using an on-board safety technology is involved in a crash. The liability concern seems to focus on on-board safety technology that fails to perform correctly, independent of cause. OEMs need to understand the 
technology, its applications, effectiveness, and the level of risk they are assuming, if the technology is to become more than an option.

\section{Reliability and Maintainability}

Manufacturers recognize that carriers need confidence in the product. The manufacturers interviewed understand that their customers - carriers and independent operators - do not want on-board systems that have the potential to malfunction and therefore take a unit out of service. An OEM's image is damaged by the release of any equipment that is unreliable and requires significant maintenance. The OEMs seemed more inclined to introduce on-board safety technology if they could feel confident that it is reliable and will require low maintenance.

\section{In-cab Technology Interface Integration}

The manufacturers also are concerned about the interoperability of the systems. The on-board safety technologies that are included in the tractor cab must integrate with existing equipment from both the technology and human interface perspectives, particularly if a device is retrofitted into a current design. Integrating new equipment is easier and more cost-effective if interface standards are in place.

\subsubsection{Device Manufacturers' Perspective}

Device manufacturers, or vendors, are suppliers to the OEMs and the aftermarket for certain products. An example of a successful vendor-supplied on-board safety technology product for large trucks is the Eaton VORAD system. Three vendors were interviewed; one declined to comment in detail as the results in Appendix B show. Therefore, the discussion that follows is more qualitative in nature.

\section{Market Demand}

Vendors are focused on issues similar to those of OEMs, although their primary customers may differ. Determining which technology is developed is driven by market demand. Several vendors interviewed are working on on-board safety technology because they believe that their market is interested in purchasing the systems. However, vendors generally indicated that technology is not readily accepted because of the newness and lack of data to prove a positive benefit-cost. Carriers that have higher value cargo or high risks such as petroleum carriers, hazardous cargo carriers, and rescue vehicles, might be more likely to consider on-board safety technologies because of the higher potential benefit.

One interviewed manufacturer stated that when 200,000 to 250,000 units are on the road, prices will come down significantly and sales will often increase. Even 100,000 units can sometimes influence prices. Also, this manufacturer stated that if a few companies successfully use onboard safety technologies, others would follow suit because it becomes a competitive advantage otherwise. 


\section{Driver Acceptance}

Vendors also recognize that users need to become accustomed to on-board safety technology benefits and be given the opportunity to provide input into the design and use of new systems. Most vendors use this approach with all their new product introductions and the same approach applies to safety technology. If customers provide input, they are more likely to accept technology because it should have the features they are looking for. Customers also will feel as if they have some ownership of the product design and will more readily accept/want the technology. The vendors agree that education is essential to encouraging acceptance, which could create market demand.

\section{Investment Required for Research and Development of New Technology}

Vendors have limited capital to invest for new products and may not have the capital necessary to bring a product such as an on-board safety technology to market even though benefit-cost analysis may indicate a positive outcome. Risks and uncertainties in the research and development needed for a new product also influence the decision to pursue the technology.

\section{Return on Investment for Purchaser}

One vendor working on the RA\&C is facing some significant costs associated with a different product (not the RA\&C) that may require a price of $\$ 4,000$. The vendor believes the system would need to be priced below $\$ 1,000$ before their customers will be interested. According to the vendors, the biggest factor in the marketplace is to show a short-term payback to the carriers.

The manufacturers indicated that deals are made and broken on a few hundred dollars per unit. The systems may sell if they can be made available in the $\$ 1,000$ to $\$ 2,000$ range and at good benefits-cost ratio. The vendor's customer must recognize and accept that purchasing an onboard safety technology for inclusion on their trucks will result in a demand by their customers, the carriers.

\section{Liability}

Vendors are also concerned about liability claims based on collected data. One pointed out that the drivers and managers should be looking at the possibility of the data supporting them rather than punishing them. One of the vendors elected to focus on passive systems because of the liability issues associated with active systems, such as the RA\&C that performs automated braking of the truck.

\subsubsection{Insurance Companies' Perspective}

The five insurance company representatives interviewed had limited awareness of on-board safety technologies. They were most familiar with the collision warning system with adaptive cruise control. 
Insurance providers voiced an interest in on-board safety technology and favor its use. While some in the industry feel they have no duty to promote safety devices, they felt they could recommend them. None of the insurers saw government mandates and regulations as an effective means of accelerating deployment of the technologies. They seem to agree that it would be better for government to provide an opportunity to understand technology better and let carriers make their own decisions.

Many truck companies are "gypsy shoppers," changing insurance companies every year or two, looking for the best deal. To the insurer, the important factor is the amount of loss experienced over the last 5 years. In other words, there is no long-lasting relationship between the insurance company and the carrier, which limits the impact of any one insurance company on the possible use of safety equipment.

One insurer indicated that a few years ago, a shortage of drivers led to many inexperienced people being hired. Not surprisingly, these drivers had more crashes than those with more experience. The economic downturn of the last 2 years resulted in fewer drivers being hired, so companies can now be somewhat more selective of applicants. As the respondent pointed out, this may be reducing the number and severity of crashes, along with better-maintained vehicles. Another insurance company respondent indicated that the number of crashes is down but the severity is up. He attributed this to increased traffic density and increased miles driven. However, this perspective could be influenced by the greater degree to which carriers are selfinsuring; the insurance companies may be seeing only the worst cases.

Several insurance company representatives suggested that the technology would be accepted more readily if it were used "as a carrot as well as a club." Nevertheless, the respondents were unsure to what extent driver satisfaction would result from this technology. Another respondent indicated he would like to see the technology used to modify drivers' behavior in a positive way-for instance, providing feedback after " $X$ " hours of use by monitor or from central dispatcher that says "Driver, you have been doing better than fleet average for " $\mathrm{X}$ " hours and therefore receive a reward (cents/mile extra or award).” Providing this feedback several times per day or on another schedule might modify driving behavior. This respondent indicated that the trucking industry does not always provide positive feedback and most of these on-board safety technologies provide information that could potentially be used for negative critiques.

\section{Demonstrated Effectiveness to Improve Safety}

The cost of insurance has gone up markedly in the last few years. In a recent survey of 1,000 carriers conducted by ATA, it was found that insurance premiums were increasing rapidly due in part to the tragic events of September 11, 2001. ATA reported that carriers renewing umbrella policies, for instance, prior to September 11 were paying 74 percent more than previously, whereas those renewing after September 11 paid an average of 120 percent more. One of the insurance companies interviewed in this task stated that insurance costs have increased, not because of bad loss experience, but because of loss of investment income on their reserves due to the poor economy. According to the interviewee, companies previously wrote insurance at a loss to acquire capital and make up the loss on investment income. Due to lower returns on invested incomes in the recent economic climate, costs for re-insurance have increased 100 to 300 percent 
in the last year or two, which makes it difficult for carriers. Also, there is a shifting of costs and exposures to motor carriers through higher deductibles and greater self-insurance.

Insurance companies establish rates based on statistical data regarding cost of repairs, repair experience, injury and death settlements, collateral property damage, environmental cleanup, and the level of co-insurance/deductibles carriers assume. Insurance companies prefer data documenting the conditions that existed in a crash. Any collected data can be used to save money in litigation. However, they recognize that the data could present a "two-edged sword" if their client is at fault. The companies will not offer premium discounts to carriers for using new systems. They believe that a mechanism already exists for this discount: fewer crashes reduce expenses and reduce premiums. However, management attitude toward safety and loss experience also matters to the insurers. Safety devices along with training and other activities are evidence of management's concern for safety.

\section{Market Image}

Insurance companies are interested in maintaining a good image with the trucking industry. Trucking companies go to insurance companies they think are reputable but they also shop for low rates. The image or reputation that an insurance company establishes has a direct impact on the size of their customer base. If on-board safety technologies can reduce crashes, insurance companies will be better able to maintain fair and equitable insurance rates.

\subsection{Summary of Industry Perspective}

According to the ATA Foundation (predecessor organization to ATRI), there are a number of overarching issues affecting the utilization of on-board safety technology in the trucking industry $\operatorname{today}^{15}$ :

- Deregulation has resulted in a competitive environment, which combined with rising insurance costs and unstable fuel costs, has eroded profit margins. As a result, technology investments must have a clear, direct, and positive benefit-cost ratio to be accepted.

- Slowing sales of new trucks and an excess of used trucks are hurting business for OEMs. Consequently, new technology systems are not typically placed on new trucks as standard equipment because it raises vehicle price. Retrofitting vehicles with new technology is often more expensive than new OEM systems.

- There is a dearth of technology vendors in the safety field and often new technology systems lack full field testing.

\footnotetext{
${ }^{15}$ ATA Foundation, “Issues Associated with the Utilization of On-board Safety Systems,” Technical Memorandum to Battelle, 2002.
} 
- Insurance costs are rising rapidly for safe and unsafe carriers alike. Unproven safety technologies typically do not qualify for discounts, making investment in them less likely.

- The industry is concerned about data privacy with on-board safety systems in that competitors might pirate data transmitted over wireless systems or data turned over to the government might be misused.

- The trucking industry, as a whole, is an extremely low-margin sector of the economy. According to Department of Commerce statistics, the industry's average operating margin was less than 5 percent in 2002. Furthermore, unstable fuel costs and skyrocketing insurance costs are dramatically affecting a company's liquidity and confidence in speculative technology investment (those technologies which do not offer a clear or immediate ROI). ${ }^{16}$

- New technologies are often beneficial from a safety standpoint because they provide users with more information and data. As technology evolves, the types and quality of captured data also evolve. However, misuse of these data by third parties and/or overreaching use by government entities can have a chilling effect on the deployment of on-board safety technologies. ${ }^{17}$

\subsection{Federal and State Regulations Related to Factors ${ }^{18}$}

Motor carriers and others serving the trucking industry must comply with Federal and state regulations developed to ensure a safe and efficient industry. Technological advances have historically preceded the development of standards, procedures, and regulations governing potential use or misuse of a technology. Traditionally, market forces have shaped regulations and standards with respect to functionality, new applications, costs, and business risks. In some instances, regulations already exist in a field where a technological advance was not anticipated. For example, requirements for paper documents and original signatures prior to the advent of the internet and e-government business were standard practice. In these cases, statutes were amended to enable new efficiencies.

One area related to adoption of on-board safety technology that is impacted by Federal regulation is accounting and taxation, specifically accounting procedures and tax laws related to technology purchase and depreciation. According to ATRI, business entities consider capital depreciation processes and procedures from internal and external perspectives at the highest level. Internal depreciation schedules, which follow Generally Accepted Accounting Principles, are typically motivated by the need to maximize resources and present a more favorable picture of a company's financial position. External depreciation in this instance refers to the interpretation of and compliance with tax codes, which can be complex in the context of Federal corporate

\footnotetext{
${ }^{16}$ American Transportation Research Institute, "Regulatory and Legal Issues Potentially Impacting the Development and Deployment of On-board Safety Technology Systems,” Technical Memorandum to Battelle, April 2003.

${ }^{17}$ ATRI, April 2003.

${ }^{18}$ ATRI, April 2003.
} 
finance and tax accounting strategies. Further, state tax codes and issues are exponentially more diverse and complex, according to ATRI. Two components of tax regulation most germane to the issue of return on investment to stakeholders focus on capital depreciation and tax credits.

The relevant Internal Revenue Service external depreciation schedule for computer-based equipment is 3 years. This connotes that the value of the investment (as a stand-alone or as portion of the overall value of a truck tractor) could be depreciated over 3 years for purchasers of on-board safety technologies, regardless of whether a technology is factory-installed or retrofit to the vehicle.

The interview survey conducted for this project (Task 5.3) as well as a recent independent survey conducted by ATRI showed that the majority of motor carriers require a break-even on their technology investments within 2 years or less. ${ }^{19}$ Revisions to tax codes allowing shorter accounting depreciation lives, or even same year deductions for the full investment amount, can improve break-even performance for on-board safety technologies. Since it is unlikely that the current accounting depreciation life of a truck tractor would be significantly reduced, incentives for factory-installed technologies could be based on the value-added of the particular system to that of the tractor.

For developers of new technologies, research and development (R\&D) costs generally contain a large proportion of capital expenditures. These costs can be depreciated over the life of the capital assets, or election can be made by the company to expense (deduct the costs from income) in the year they are incurred. This election is binding for the year it is made and for all later years.

The evolving nature of on-board safety technology, having limited exposure in the marketplace, is indicative of the limited regulatory environment that relates to them according to ATRI. Through consultation with financial, legal, and regulatory experts within the trucking industry, ATRI's analysis revealed that current regulations do not create explicit impediments to the development and deployment of the technologies.

\subsection{Conclusions}

The following conclusions and observations are drawn from the results of this task:

- The primary decision maker or customer for the RA\&C (or for on-board safety technology in general) is the motor carrier.

- The primary factor driving the purchase decision is that the carrier must see that the RA\&C will provide an acceptable payback or return on investment within 24 months; preferably 12 to 18 months or less.

- Related to ROI but a separate factor is that the purchase cost of the RA\&C should be no more than $\$ 2,000$ and preferably less than $\$ 1,000$.

\footnotetext{
${ }^{19}$ American Transportation Research Institute/Gartner G2, Trucking Technology Survey Results Summary, 2003.
} 
- All interviewed stakeholders expressed a strong need to see proof of effectiveness of the technology to improve safety.

- All interviewed stakeholders also share a desire to have confidence in the reliability and maintainability of the technology. Part of this factor is also proof that the technology has no undesirable characteristics such as false positives.

- Acceptance of the technology by the driver is also important. The in-cab interface must be user friendly, not unduly add to the complexity of the cab, not distract the driver nor cause the driver concern about losing control of his/her vehicle.

- All of the above support the development of market demand which was cited by the OEMs and vendors as a key factor and necessary prerequisite for deployment of the technology.

- The observation from both the interviews and the workshop is that there is low awareness in general of on-board safety technology, but especially low awareness of the RA\&C. Fewer than half of the 19 carriers interviewed had any awareness at all of the RA\&C and those that did describe their awareness as vague. Only one of the five insurers interviewed expressed awareness of the RA\&C. None of the drivers interviewed had experience with the RA\&C.

- Although awareness of the technology is not listed as a formal decision factor, it is a precursor to creating market demand for the product.

- The RA\&C has completed a successful FOT. It also has demonstrated efficacy in preventing rollover under controlled testing conditions. Further, the cost of the RA\&C was documented in the FOT to be less than $\$ 1,000$ including the addition of traction control, an option needed for effective operation of the RA\&C but having its own benefits beyond that. 


\section{Acronyms}

ABS Antilock Braking system

ATA American Trucking Associations

ATRI American Transportation Research Institute (successor to the ATA Foundation)

AVI Automatic Vehicle Identification

CDL Commercial Driver's License

CRADA Cooperative Research and Development Agreement

CVO Commercial Vehicle Operations

CVSA Commercial Vehicle Safety Administration

CWS/ACC Collision Warning System with Adaptive Cruise Control

DHS Department of Homeland Security

ECBS Electronically Controlled Braking System

EDI Electronic Data Interchange

FMCSA Federal Motor Carrier Safety Administration

FMVSS Federal Motor Vehicle Safety Standards

FOT Field Operational Test

GPS Global Positioning System

GVWR Gross Vehicle Weight Rating

ITS Intelligent Transportation System

IVI Intelligent Vehicle Initiative

LDWS Lane-Departure Warning System

NHTSA National Highway Traffic Safety Administration

OEM Original Equipment Manufacturer

OOIDA Owner-Operator Independent Drivers Association

RA\&C Roll Advisor and Controller

ROI Return on Investment

RSA Roll Stability Advisor

RSC Roll Stability Controller

TREAD Transportation Recall Enhancement, Accountability, and Documentation (Act)

TSA Transportation Security Administration

USDOT U.S. Department of Transportation

WIM Weigh-in-Motion 


\section{Appendix A:}

Interview Guides for Manufacturers, Vendors, Drivers, and Insurance Companies 
Trucking Industry Perspectives on

\section{TECHNOLOGY-BASED SAFETY SYSTEMS}

INTRODUCTION: BATTELLE IS WORKING WITH THE DEPARTMENT OF TRANSPORTATION TO IDENTIFY WAYS TO ACCELERATE DEPLOYMENT OF SEVERAL NEW INTELLIGENT VEHICLE SAFETY TECHNOLOGIES. CAN YOU PARTICIPATE IN A BRIEF DISCUSSION [10 TO 15 MINUTES] OR SUGGEST A MORE CONVENIENT TIME? OTHER PERSON(S)?

THE ON-BOARD SAFETY SYSTEMS WE ARE FOCUSING ON ARE

- COLLISION WARNING SYSTEM(CWS)

- AdAPTIVE CRUiSe CONTROl (ACC)

- ROll ADVISOR AND CONTROL (RA\&C)

- LANe Departure WARNing (LDW).

-

WE WILL PROVIDE BRIEF DESCRIPTIONS OF THESE SYSTEMS TO YOU, AND ASK FOR YOUR ASSESSMENT OF THEM. BUT FIRST, WE WOULD LIKE TO DISCUSS INDUSTRY ATTITUDES TOWARDS INTELLIGENT SAFETY TECHNOLOGIES IN GENERAL.

\section{QUESTIONS:}

1. A. WHAT IN-VEHICLE SAFETY TECHNOLOGIES OR SYSTEMS ARE BEING USED BY THE TRUCKING INDUSTRY THAT YOU ARE AWARE OF:

B. WHO IS USING THEM AND CAN YOU DESCRIBE HOW THEY ARE USED?

C. WHAT DOES THE REST OF THE INDUSTRY THINK ABOUT THESE SAFETY SYSTEMS?

2. PLEASE INDICATE HOW MUCH IMPACT THE FOLLOWING FACTORS HAVE IN A TRUCKING COMPANY'S DECISION TO BUY AND USE IN-VEHICLE SAFETY TECHNOLOGIES (EITHER RETROFIT OR AS ORIGINAL TRUCK EQUIPMENT): (1=NOT IMPORTANT; 5=VERY IMPORTANT):

COST TO INSTALL AND MAINTAIN

COST TO TRAIN DRIVERS IN USE

OVERALL DRIVER SATISFACTION/REDUCED TURNOVER DRIVER ACCEPTANCE OF A SYSTEM

ACCURACY AND RELIABILITY OF A SYSTEM 
EFFECTIVENESS OF A SYSTEM IN IMPROVING

SAFETY

INSURANCE COMPANY REQUIREMENT

REDUCED INSURANCE PREMIUMS

REDUCED ACCIDENT-RELATED COSTS

OTHER, PLEASE SPECIFY:

OTHER, PLEASE SPECIFY:

3. PLEASE RANK IN ORDER OF IMPORTANCE, WHO YOU BELIEVE IS MOST RESPONSIBLE FOR INTRODUCING NEW TRUCKING SAFETY TECHNOLOGIES INTO THE MARKETPLACE

(1=MOST IMPORTANT; 7=LEAST IMPORTANT):

$\begin{array}{ll}- & \text { TRUCK TRACTOR MANUFACTURERS } \\ & \text { TRUCK TRAILER MANUFACTURERS } \\ & \text { COMPONENT MANUFACTURERS } \\ \square & \text { TRUCKING COMPANIES } \\ & \text { TRUCK DRIVERS } \\ \square & \text { INSURANCE COMPANIES } \\ & \text { GOVERNMENT }\end{array}$

FOR THOSE GROUPS RANKED \# 1,2,3, WHICH COMPANIES ARE THE LEADERS? WHO WITHIN THE COMPANIES (BY TITLE OR NAME) ARE THE DECISION MAKERS?

4. WHAT ARE THE MAJOR OBSTACLES, BARRIERS, OR CONCERNS TO INVESTING AND INCORPORATING NEW SAFETY TECHNOLOGIES/SYSTEMS INTO THE TRUCKING INDUSTRY?

5. WHAT ROLE COULD THE TRUCKING INDUSTRY PLAY IN BRINGING NEW SAFETY TECHNOLOGIES/ SYSTEMS TO THE MARKET? 
6. WHAT ROLE COULD MANUFACTURERS PLAY IN BRINGING NEW SAFETY TECHNOLOGIES/SYSTEMS TO THE MARKET?

7. WHAT ROLE COULD GOVERNMENT PLAY IN BRINGING NEW SAFETY TECHNOLOGIES/SYSTEMS TO THE MARKET?

8. LET'S TAKE A FEW MINUTES TO DISCUSS THE SPECIFIC SAFETY TECHNOLOGIES WE ARE FOCUSED ON (PROVIDE DESCRIPTIONS). BASED ON THESE DESCRIPTIONS, WOULD THE TRUCKING INDUSTRY BE INTERESTED IN ADOPTING THE SYSTEMS, WHY/WHY NOT, AND AT WHAT MAXIMUM RANGE OF INITIAL PER-VEHICLE COST:

\section{SAFETY SYSTEM 1: CWS}

TRUCKING INDUSTRY WOULD BE INTERESTED IN THE SYSTEM? $\quad$ YES $\square \quad$ No $\square$ WHY/WHY NOT?

IF YES, WHAT INITIAL MAXIMUM PRICE RANGE PER VEHICLE:

$\square$ LESS THAN \$500 $\quad \square$ \$501 TO \$1,000 $\square$ \$1,001 TO \$1,500
$\square$ \$1,501 TO \$2,500 $\quad \square$ GREATER THAN \$2,500


SAFETY SYSTEM 2: ACC

TRUCKING INDUSTRY WOULD BE INTERESTED IN THE SYSTEM? $\quad$ YES $\square \quad$ No $\square$ WHY/WHY NOT?

IF YES, WHAT INITIAL MAXIMUM PRICE RANGE PER VEHICLE:

$\square$ LESS THAN $\$ 500 \quad \square \$ 501$ TO $\$ 1,000 \quad \square \$ 1,001$ TO $\$ 1,500$

$\square$ \$1,501 TO \$2,500 $\square$ GREATER THAN \$2,500

SAFETY SYSTEM 3: RA\&C

TRUCKING INDUSTRY WOULD BE INTERESTED IN THE SYSTEM? $\quad$ YES $\square \quad$ No $\square$ WHY/WHY NOT?

IF YES, WHAT INITIAL MAXIMUM PRICE RANGE PER VEHICLE:

$\square$ LESS THAN \$500 $\square \$ 501$ TO \$1,000 $\square \$ 1,001$ TO $\$ 1,500$

$\square$ \$1,501 TO \$2,500 $\square$ GREATER THAN \$2,500

SAFETY SYSTEM 4: LDW

TRUCKING INDUSTRY WOULD BE INTERESTED IN THE SYSTEM? $\quad$ YES $\square \quad$ No $\square$ WHY/WHY NOT?

IF YES, WHAT INITIAL MAXIMUM PRICE RANGE PER VEHICLE:

$\square$ LESS THAN $\$ 500 \quad \square \$ 501$ TO $\$ 1,000 \quad \square \$ 1,001$ TO $\$ 1,500$
$\square \$ 1,501$ TO $\$ 2,500 \quad \square$ GREATER THAN $\$ 2,500$

THANK YOU FOR YOUR TIME AND INTEREST. IF WE HAVE FURTHER QUESTIONS, MAY WE CALL YOU AGAIN? WHO ELSE AT YOUR COMPANY SHOULD WE SPEAK WITH? WHO ELSE IN THE INDUSTRY SHOULD WE SPEAK WITH? 


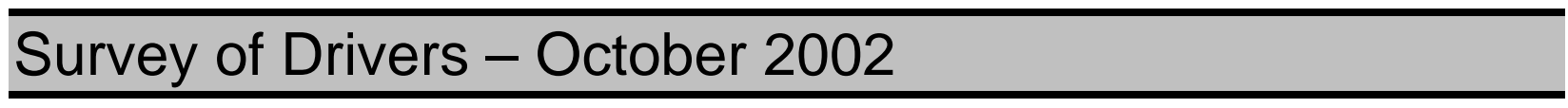

\section{Date}

Location

\section{Ground Rules}

(1) All interviews are confidential.

(2) Battelle's role as independent evaluator.

(3) Purpose to discuss experiences with safety technologies.

(4) Looking for objective feedback, both pros and cons.

\section{Introduction}

(1) First name/handle (optional)

(2) Inter/intra state travel (dedicated?)

(3) Owner-Op, How many trucks in your fleet? Ave. trip length (mi.)? (Team?)

(4) How many years driving experience?

(5) How long have you been driving for this company?

(6) What do you haul/trailer type? Auto, Bx, Blk, Dmp, F, HM, LB, Lvstk, R, T 


\section{Experience with Truck Safety Technologies}

Which of the following safety systems have you ever used? Which are you currently using on your truck? Of those you currently use, how long have you been using them? If not a user, would you be willing to try? Which are (would be) most useful to you (rank top 3)? [Add any other safety systems the respondent reports using.]

\begin{tabular}{|c|c|c|c|c|c|c|}
\hline & $\begin{array}{c}\text { Safety System } \\
\text { Type }\end{array}$ & $\begin{array}{l}\text { Ever Used? } \\
\quad \mathrm{Y} / \mathrm{N}\end{array}$ & $\begin{array}{l}\text { Currently } \\
\text { Using? } \\
\text { Y / N }\end{array}$ & $\begin{array}{l}\text { Years/Months } \\
\text { of Experience? }\end{array}$ & $\begin{array}{l}\text { Willing to Try? } \\
\text { Y / N }\end{array}$ & $\begin{array}{l}\text { Usefulness? } \\
\text { Rank } 1^{\text {st }}, 2^{\text {nd }}, 3^{\text {rd }}\end{array}$ \\
\hline a. & ABS & & & & & \\
\hline b. & $\begin{array}{l}\text { Electronic disc brakes } \\
\text { - like ABS-advanced } \\
\text { braking system (ECBS) }\end{array}$ & & & & & \\
\hline c. & $\begin{array}{l}\text { In-Vehicle Navigation } \\
\text { (GPS) }\end{array}$ & & & & & \\
\hline d. & $\begin{array}{l}\text { Lane Tracking/Lane } \\
\text { Departure Warning }\end{array}$ & & & & & \\
\hline & Pre-Pass & & & & & \\
\hline f. & $\begin{array}{l}\text { Rollover advisory } \\
\text { system }\end{array}$ & & & & & \\
\hline g. & Rollover control system & & & & & \\
\hline h. & $\begin{array}{l}\text { Smart-Cruise-Fixed } \\
\text { Following Distance- } \\
\text { adaptive cruise control }\end{array}$ & & & & & \\
\hline i. & $\begin{array}{l}\text { [VORAD] forward-radar } \\
\text { following distance- } \\
\text { noise/visual alerts }\end{array}$ & & & & & \\
\hline j. & $\begin{array}{l}\text { Warning of blind spots } \\
\text { - side-looking radar }\end{array}$ & & & & & \\
\hline
\end{tabular}




\section{Training in the Use of Truck Safety Systems (where applicable)}

Have you ever received training in the use of any of these safety systems? How effective was that training? Rank the training you received on a scale from 1 to 5 , where $1=$ Very effective/useful and $5=$ ineffective/not useful.

[Skip those never used from Q III, and include other systems from Q III.]

\begin{tabular}{|l|l|l|}
\hline Safety System Type & \multicolumn{1}{c|}{$\begin{array}{c}\text { Ever Received } \\
\text { Training? } \\
\text { Y / N }\end{array}$} & $\begin{array}{c}\text { Effectiveness of } \\
\text { Training? } \\
1-2-3-4-5\end{array}$ \\
\hline a. ABS & & \\
\hline b. Electronic disc brakes - like ABS-advanced braking system (ECBS) & & \\
\hline c. In-Vehicle Navigation (GPS) & & \\
\hline d. Lane Tracking/Lane Departure Warning & & \\
\hline e. Pre-Pass & & \\
\hline f. Rollover advisory system & & \\
\hline g. Rollover control system & & \\
\hline h. Smart-Cruise-Fixed Following Distance-adaptive cruise control & & \\
\hline i. $\quad$ VORAD] forward-radar following distance-noise/visual alerts & & \\
\hline j. $\quad$ Warning of blind spots - side-looking radar & & \\
\hline k. $\quad$ I. $\quad$ in & & \\
\hline
\end{tabular}




\section{Learning/Training Preference}

A. How do you personally like to hear about new safety technology? What is the best way? $2^{\text {nd }}$ ? $3^{\text {rd}}$ ? What's worst?

B. How do you personally like to learn to use these technologies? What is the best way? $2^{\text {nd }}$ ? $3^{\text {rd }}$ ? What's worst?

\begin{tabular}{|c|c|c|c|}
\hline Learning/Training Method & $\begin{array}{l}\text { Rank Top Three } \\
\text { (how you want to } \\
\text { hear about it) } \\
1-2-3-W\end{array}$ & $\begin{array}{c}\text { Rank Top Three } \\
\text { (ways to learn to } \\
\text { use it) } \\
1-2-3-W \\
\end{array}$ & Comments/what system? \\
\hline a. Actual Road experience training? & & & \\
\hline b. $\quad \mathrm{CB}$ ? & & & \\
\hline $\begin{array}{ll}\text { c. } & \begin{array}{l}\text { Formal classroom/company orientation } \\
\text { training? }\end{array} \\
\end{array}$ & & & \\
\hline d. Government mandate? & & & \\
\hline e. Internet/e-mail/Web - computer & & & \\
\hline $\begin{array}{l}\text { f. Magazines (i.e., Heavy-Duty Trucking, } \\
\text { OTR, Owner-Operator) }\end{array}$ & & & \\
\hline $\begin{array}{l}\text { Message over company } \\
\text { communication system? }\end{array}$ & & & \\
\hline h. On-site orientations or ride-alongs? & & & \\
\hline i. $\quad$ Read manuals? & & & \\
\hline j. $\quad$ Simulator or test track trials? & & & \\
\hline k. Talk with other drivers? & & & \\
\hline I. Trial and error/Hands on? & & & \\
\hline m. Truck shows? & & & \\
\hline n. Other? & & & \\
\hline
\end{tabular}




\section{Driver Attitudes Regarding The Use of Truck Safety Systems in General}

I'm going to read a number of statements about these safety systems, and I would like you to tell me how much you agree or disagree with the statement. Again, the scale goes from 1 to 5 where $1=$ Strongly Agree and $5=$ Strongly Disagree. [Give respondent answer card with response categories.]

\begin{tabular}{|c|c|c|}
\hline Statement & $\begin{array}{c}\text { Which } \\
\text { system(s)? }\end{array}$ & $\begin{array}{c}\text { Strongly Agree }=1 \\
\text { Agree }=2 \\
\text { Neutral }=3 \\
\text { Disagree }=4 \\
\text { Strongly Disagree }=5 \\
\end{array}$ \\
\hline \multicolumn{3}{|l|}{ a. (I think some of) these systems (could) help me save time on my trips. } \\
\hline \multicolumn{3}{|l|}{ b. (I think some of) these systems (could) help me respond faster in emergency situations. } \\
\hline \multicolumn{3}{|l|}{ d. I (would) feel safer driving with these systems than without them. } \\
\hline \multicolumn{3}{|l|}{$\begin{array}{l}\text { e. (I think) these systems (could) increase my driving workload; that is, they increase the amount } \\
\text { of effort and concentration it takes to drive. How? }\end{array}$} \\
\hline \multicolumn{3}{|l|}{ g. These safety systems help reduce the stress and fatigue of truck driving. } \\
\hline \multicolumn{3}{|l|}{$\begin{array}{l}\text { h. I find I have (could) become dependent on these safety systems such that I (might) feel less } \\
\text { safe in a truck without them. }\end{array}$} \\
\hline \multicolumn{3}{|l|}{ i. Most of the drivers I know would rather have these systems than not have them in their trucks. } \\
\hline $\begin{array}{l}\text { j. I (would) sometimes keep some of these systems turned off in my truck while I am driving. } \\
\text { Which? Why? }\end{array}$ & & \\
\hline \multicolumn{3}{|l|}{$\begin{array}{l}\text { k. To really make a safety improvement, every truck on the road should have these kinds of } \\
\text { systems. }\end{array}$} \\
\hline \multicolumn{3}{|l|}{$\begin{array}{l}\text { n. I trust the reliability of these safety systems. What specific concerns? } \\
\text { Describe why }\end{array}$} \\
\hline \multicolumn{3}{|l|}{ o. These systems (may) interfere with my driving tasks. How? } \\
\hline \multicolumn{3}{|l|}{ p. Having these systems has not really changed (probably won't change) the way I drive. } \\
\hline \multicolumn{3}{|l|}{ q. Overall, I (would) really like (to have) having these safety systems on my truck. } \\
\hline \multicolumn{3}{|l|}{$\begin{array}{l}\text { r. My company/customers feel(s) it is important to install these kinds of safety systems in their } \\
\text { (our) fleet. }\end{array}$} \\
\hline $\begin{array}{l}\text { s. I would like to encourage (the decision makers) my company to outfit trucks with (more) safety } \\
\text { systems like these. }\end{array}$ & & \\
\hline
\end{tabular}




\section{Wrap Up}

Do you have any suggestions for making further safety improvements? (vehicles, drivers, infrastructure)

Are there any other technologies you would like to have on your truck that you do not currently have?

How would you like new safety technology to be introduced?

Past three years: Crash? Violations? N/A? (optional)

Any other comments you would like to make?

That concludes our interview. Thanks for sharing your thoughts and time with me. 


\section{Appendix B:}

\section{Detailed Interview Results}


Appendix B summarizes the interview results for manufacturers, buyers and users of on-board safety technology. Before interviewing each stakeholder group, questionnaires were developed to structure the interviews and obtain consistent information from the interviewees. It was found that the structured interviews worked well with the carriers, drivers, and insurance companies, but did not work well with the OEMs. The OEM interviews followed a more informal discussion session, but good information was obtained. The carriers, drivers, and driver-owners were willing to follow the questionnaire process.

The following summarizes the results obtained from the interview process. Section B-1 presents the information provided by the OEMs and vendors, Section B-2 summarizes the motor vehicle carrier responses, Section B-3 summarizes the drivers and independent owner-operators, and Section B-4 summarizes the insurance company responses. Each section begins with an explanation of the interview process and/or any interview questionnaire used in the interviews. 


\section{B-1. Original Equipment Manufacturers (OEMs) and Vendors}

Original Equipment Manufacturers are the builders of the tractors and trailers. Vendors include those companies that manufacture equipment for tractors and trailers and supply the OEMs or after-market suppliers. Originally a formal questionnaire was developed to structure the interviews. The questionnaire was abandoned early in the interview process because OEMs and vendors struggled following the established agenda. The following information was obtained from the interviews:

Interview \#1 (OEM)

Technology Familiarity

- Familiar with collision warning systems (CWS) and automated cruise control (ACC), such as the Eaton VORAD system.

- Familiar with rollover stability control but to a lesser extent than CWS and ACC.

- There are not a lot of requests for on-board safety technology, and those that are available (i.e., CWS and ACC) are not ordered.

- Historically, on-board safety technologies get purchased about 10 percent to 20 percent in new orders.

Cost/Financial Benefit

- The vendor makes what customers will buy.

- Equipment must add to the bottom line and there must be a payoff.

- Even $\$ 1,000$ to $\$ 2,000$ is important to customers in a $\$ 120,000$ purchase. Prices just went up because of added costs to engines to meet new emission controls.

- If a financial benefit can be shown for on-board safety technology, the acceptance rate is high.

- Financial benefits are hard to measure because the equipment has not had extensive use. The historical real-world data is not there.

- Cost and financial benefits are more important than the effectiveness of a system in improving safety.

Technical Assurance

- Carriers need confidence in the products before they will purchase them.

- Truckers exhibit skepticism in technology. They must be convinced of benefits before they will use on-board safety technology. History has proven that if the trucker does not believe in the on-board safety technology, they often will disable/sabotage it if possible.

- The on-board safety technology cannot take the truck out of service for maintenance very often. Reliability and maintainability is required.

- The system must function under all conditions (i.e., weather, terrain, speed, congestion levels, etc.)

Driver Acceptance

- Drivers do not like to give up control. If the on-board safety technology takes control from the driver, he or she tend to disable it if they can.

- Drivers' opinions are becoming more important in on-board safety technologypurchasing decisions. 
- If the on-board safety technology takes the trucks out of service more than trucks without the systems, drivers discourage buying those truck brands.

Additional comments

- There has not been a willingness by the insurance companies to reduce rates due to onboard safety technology use.

- There has not been a willingness by the public sector to provide tax incentives to stimulate on-board safety technology sales.

- The Government often uses incentives to force marginal use of on-board safety technology and any incentives are temporary. When the incentive goes away, the carriers are left with added expenses.

- It is often difficult to get the various stakeholders in the transportation industry to work together.

- Government needs to take an active role in rational reasoning.

\section{Interview \#2 (OEM)}

- Willingness to pay for on-board safety technology is a function of how it will provide a positive return to the carriers.

- On-board safety technologies should be targeted. For example, small carriers that work within city limits will not be interested in CWS/ACC, whereas long line haul carriers may be more interested in these technologies.

- On-board safety technology is currently a pull market for OEMs. They produce what the customer asks for.

- The buyers (i.e., carriers and independent owner-drivers) need to see on-board safety technologies saving money by reducing accidents or reducing insurance premiums before they are willing to buy.

\section{Interview \#3 (OEM)}

- On-board safety technology will only be accepted when the customer can see a return on investment and that needs to be very clear. Return on investment is probably the most important information to encourage the use of on-board safety technologies.

- Returns most likely will come from reductions in insurance rates, workman's compensation, or accident rates.

- Fleet size makes a difference. Large fleets may not see the benefit needed because of the high cost to equip their fleet. On the other hand, small fleets might be able to afford it and only one accident might make a difference.

- On-board safety technology equipment should be targeted to different operational environments. For example, military convoys might benefit from rear-end collision avoidance.

- It typically takes over 4 years to move an on-board safety technology from being provided as an option to being offered as standard equipment.

- On-board safety technology is promoted through operating/sales/safety aspects. 
Interview \#4 (Vendor)

- Vendors are driven by what their customers will buy.

- The major issues in the purchase of on-board safety technologies are price and return on investment (ROI).

- On-board safety technology equipment is not selling.

- On-board safety technologies must be affordable. A current on-board safety technology made by this vendor is priced at $\$ 4,000$ per unit and is too expensive and will probably only receive limited acceptance. All these systems need to get below $\$ 1,000$ per unit to receive substantial interest.

- If an on-board safety technology can show positive benefit, government mandating can be effective.

- On-board safety technologies requiring infrastructure changes will be slow to be adopted. This could be a very costly proposition.

- Drivers are very leery of how on-board safety technology data will be used. Both drivers and carriers are concerned about liabilities and use of the data for litigation. Drivers are concerned their driver performance will be evaluated using the data.

- This vendor felt that on-board safety technology should be mandated to insure use. Most vendors, carriers, and drivers disagree.

Interview \#5 (Vendor) (very reluctant to be interviewed)

- Must reduce costs and increase visible cost savings.

Interview \#6 (Vendor)

- Upfront costs to purchase are important but fleet managers also consider long-term paybacks.

- All must do a better job identifying benefits to encourage on-board safety technology use.

- Public awareness of benefits will provide public relations encouragement. Often, awareness of technology benefits is a problem.

- $\quad$ Sometimes a few aggressive companies will try on-board safety technology (i.e., FOTs). If they are successful, others will follow suit because it becomes a competitive advantage otherwise.

- When 200,000 to 250,000 units are on the road, prices will come down significantly and sales will often increase. Even 100,000 units can sometimes influence price.

- Insurance companies can encourage use through rate reductions for technology that can statistically be shown to avoid accidents.

- One of the problems is how/where to incorporate an on-board safety technology in a cab and getting drivers to accept another high technology gadget.

\section{Interview \#7 (OEM)}

- In the United States, every truck is custom designed for a customer. Therefore, it is much harder to develop and sell cost-effective new products and to introduce new technology. The European market buys what the OEMs make for them and the more standard equipment has allowed the OEMs to introduce new technology faster than in the United States. 
- The biggest difficulty in the marketplace is to show a short term payback to the carriers. Customers must see a benefit and a way to reduce overall costs.

- Fleet costs can be high. A carrier ordering 100 trucks and buying a \$1,000 on-board safety technology system results in $\$ 100,000$ of additional cost.

- In some cases, the payback is not materializing because the insurance companies do not want to reduce rates without 3 to 5 years of data.

- Products must be user friendly.

- Early bad experiences with devices can create bad public relations. This can damage sales for a long time. It is then a hurdle for new technology to overcome in order to be accepted.

- Tax incentives might be a way to encourage on-board safety technology acceptance. (DOE seems to be having some success with tax incentives for hybrid vehicles).

- Some carriers and truckers do not want recording devices tracking them. Both fear that the data will be used to penalize them.

- Customer expectations are that the various safety systems will each cost about the same amount of dollars.

Interview \#8 (OEM)

- Technology must be commercially viable (affordable) and feasible. If it is so expensive that it eliminates profitability, it is not feasible.

- Don't use profitability as a driver but show at the very least no commercial penalty and hopefully some commercial/population benefit.

- The technology must be reliable. There is a need to show that the technology works and that false positives won't occur.

- It is important to get the customer involved and understand what they want and need in terms of on-board safety technology.

- The on-board safety technology must be validated. It must be shown to work in the realworld under real operating conditions.

- Larger carriers will embrace on-board safety technology sooner because of the larger capital availability. Smaller carriers will be slower to incorporate new technology.

- Cost is an issue. A few thousand dollars added to a new vehicle must be justifiable. Deals are made on a few hundred dollars per unit. These systems will sell in the $\$ 1,000$ to $\$ 2,000$ range.

- OEMs should continue to partner with USDOT to pursue new technology. 
The following summarizes provides a statistical summary for common items mentioned by the OEM/vendors in the interviews performed:

\begin{tabular}{|c|c|}
\hline $\begin{array}{l}\text { Decision Criteria } \\
\end{array}$ & Number of Responses \\
\hline 1. OEMs/vendors make what the market will buy. & 5 \\
\hline 2. $\quad$ On-board safety technology cost is the most important criteria. & 7 \\
\hline $\begin{array}{l}\text { 3. Payback must be shown in } 12 \text { to } 18 \text { months. Equipment must add to the bottom } \\
\text { line. }\end{array}$ & 3 \\
\hline $\begin{array}{l}\text { 4. There is price sensitivity to the purchase price of on-board safety technology. } \\
\text { Customers seem to be willing to pay up to about } \$ 2,000 \text {. }\end{array}$ & 5 \\
\hline $\begin{array}{l}\text { 5. Buyers need confidence that the on-board safety technology products work } \\
\text { before they will readily buy them. }\end{array}$ & 6 \\
\hline $\begin{array}{l}\text { 6. It is important to include buyers early in the design and testing of the on-board } \\
\text { safety technology systems. }\end{array}$ & 2 \\
\hline 7. On-board safety technology must have low maintenance requirements. & 2 \\
\hline Drivers are reluctant to give up control of the vehicle. & 1 \\
\hline $\begin{array}{l}\text { 9. Drivers are becoming more important in the on-board safety technology } \\
\text { purchasing decisions. }\end{array}$ & 1 \\
\hline 10. Carriers and drivers are very sensitive to how any collected data will be used. & 3 \\
\hline $\begin{array}{l}\text { 11. Without being mandated, on-board safety technology gets purchased about } 10 \% \\
\text { to } 20 \% \text { of the time. }\end{array}$ & 1 \\
\hline $\begin{array}{l}\text { 12. Insurance companies have not reduced rates for trucks with on-board safety } \\
\text { technology. Insurance companies want } 3 \text { to } 5 \text { years of experience to evaluate } \\
\text { crash reductions. }\end{array}$ & 3 \\
\hline 13. Tax incentives might encourage use of on-board safety technology. & 2 \\
\hline $\begin{array}{l}\text { 14. Large fleets will readily invest in on-board safety technology than smaller fleets } \\
\text { or independent owner-drivers. }\end{array}$ & 2 \\
\hline $\begin{array}{l}\text { 15. On-board safety technology should be targeted to different carrier applications. } \\
\text { Urban carriers might need different on-board safety technology than rural } \\
\text { carriers. }\end{array}$ & 2 \\
\hline $\begin{array}{l}\text { 16. It typically takes more than } 4 \text { years to move from on-board safety technology } \\
\text { being offered as an option to standard equipment. }\end{array}$ & 1 \\
\hline $\begin{array}{l}\text { 17. Government mandating can be effective to getting carriers to use on-board } \\
\text { safety technology. }\end{array}$ & 1 \\
\hline $\begin{array}{l}\text { 18. Human factors and ease of use is important in customer decisions to buy on- } \\
\text { board safety technology. }\end{array}$ & 2 \\
\hline
\end{tabular}




\section{B-2. Motor Vehicle Carriers}

Interviews with motor vehicle carriers used the questionnaire presented in Appendix A. Nineteen carriers were interviewed. The information obtained in the interviews is summarized below:

Question 1A. What in-vehicle safety technologies are you using?

\begin{tabular}{|c|c|}
\hline Carrier & Answer \\
\hline 1 & None \\
\hline 2 & None \\
\hline 3 & None; only intelligence in cab is the driver. \\
\hline 4 & None \\
\hline 5 & $\begin{array}{l}\text { Using extra mirrors on cabs and computer controlled engine speed that is checked regularly. } \\
\text { (person was not aware of IVI technologies) }\end{array}$ \\
\hline 6 & None \\
\hline 7 & None \\
\hline 8 & None \\
\hline 9 & Using the Eaton VORAD collision avoidance system on about 420 of 450 company trucks. \\
\hline 10 & Not applicable \\
\hline 11 & None \\
\hline 12 & Not applicable \\
\hline 13 & Eaton VORAD was used and then removed. \\
\hline 14 & None \\
\hline 15 & $\begin{array}{l}\text { Testing Eaton VORAD collision warning systems without ACC on } 4 \text { units. Started test } 6 \\
\text { months ago. }\end{array}$ \\
\hline 16 & $\begin{array}{l}\text { Currently using } 2 \text { systems; on-board data processors/recorders for accident reconstruction, } \\
\text { speed, and idle control. Also using rear-facing video cameras to reduce backing accidents. }\end{array}$ \\
\hline 17 & None \\
\hline 18 & None (“Don’t think so.”) \\
\hline 19 & $\begin{array}{l}\text { Tested Eaton VORAD collision warning system for six months about one year ago. } \\
\text { Discontinued use of the system because no appreciable difference was detected. Other than } \\
\text { the Qualcom Omnitracs satellite communications and tracking system, the company does not } \\
\text { use any on-board technologies in trucks. }\end{array}$ \\
\hline
\end{tabular}

From the interview results, it is clear that only a few of the carriers were really aware of onboard safety technologies. Most of the people interviewed were either sales and marketing people or people from engineering. It is felt (Battelle opinion) that on-board safety technology concepts should have been familiar with these stakeholders if the systems were marketed. 
Question 1B. What [other] in-vehicle technologies or systems are you aware of? Who do you know that is using them?

\begin{tabular}{|c|c|}
\hline Carrier & Answer \\
\hline 1 & None \\
\hline 2 & $\begin{array}{l}\text { Fatigue } 8 \text { - a video on fatigue management. Freightliner uses through speakers of truck. Had a } \\
\text { company presentation on backup detectors. Also mentioned the VORAD following and lane } \\
\text { change system. }\end{array}$ \\
\hline 3 & None \\
\hline 4 & $\begin{array}{l}\text { Aware of crash avoidance systems such as VORAD; backup systems using TV monitors; } \\
\text { signal system that the truck is closing on the vehicle in front; a radar signal system for blind } \\
\text { spots; Knew that US Xpress was using some safety systems; also aware of electronic boxes to } \\
\text { track driving service such as electronic logging. }\end{array}$ \\
\hline 5 & None \\
\hline 6 & $\begin{array}{l}\text { Aware that some companies were using technologies in the cab to help back the truck. Assume } \\
\text { they were referring to video cameras. }\end{array}$ \\
\hline 7 & None \\
\hline 8 & None \\
\hline 9 & $\begin{array}{l}\text { US Xpress is testing anti-rollover technology but not familiar with it. (note this could have } \\
\text { been the Praxair rollover advisory system) }\end{array}$ \\
\hline 10 & $\begin{array}{l}\text { Driver alertness system such as PERCLOS (a camera in the vehicle to estimate alertness). Eye } \\
\text { tracking to determine fatigue was discussed at the TRB meeting. Don't test systems but was } \\
\text { interested in a lot of different safety technologies. Was fairly aware of rest of trucking } \\
\text { industry's interest in ISS. Reviewing videos from Human Factors and Ergonomics Association } \\
\text { (Forensic Professional Group) in California related to ISS. Not as familiar with rollover } \\
\text { warning systems and felt that was of less interest except to tank carriers. }\end{array}$ \\
\hline 11 & $\begin{array}{l}\text { Aware of VORAD and Altra technologies which are sensors for blind spot and/or backing. } \\
\text { Didn't know of anyone using them. }\end{array}$ \\
\hline 12 & $\begin{array}{l}\text { Aware of larger carriers using on-board recorders but not seeing much in safety systems. In } \\
\text { October } 2001 \text { had a seminar on Eaton VORAD and liked the system. However was not } \\
\text { planning to incorporate the system because of cost. }\end{array}$ \\
\hline 13 & Devices to check eyes and lane changing warning systems. \\
\hline 14 & $\begin{array}{l}\text { Read all about many of them in the transport magazines. Remembered systems to } \\
\text { monitor/alert on following intervals and lane changes. }\end{array}$ \\
\hline 15 & $\begin{array}{l}\text { Not familiar with systems we were testing except for the Eaton VORAD collision warning } \\
\text { system. }\end{array}$ \\
\hline 16 & $\begin{array}{l}\text { Aware of the Eaton VORAD system and considering a pilot test with } 100 \text { in-city vehicles. } \\
\text { Person thought it would reinforce or modify driving behavior and therefore would like to see it } \\
\text { in their driver training system. Company had seen } 25 \% \text { decrease in backing accidents since } \\
\text { installing video cameras. However he did say that they simultaneously instituted a driver- } \\
\text { training program emphasizing backing types of incidents. So not sure which cause-effect } \\
\text { relationship was valid. }\end{array}$ \\
\hline 17 & Aware of GPS and collision warning. \\
\hline 18 & $\begin{array}{l}\text { Aware of VORAD, a black box to keep log of hours, pre-pass transponders for scales, } \\
\text { automated cruise control, and highway notification systems. }\end{array}$ \\
\hline 19 & $\begin{array}{l}\text { Aware of VORAD system, collision avoidance systems, and a system with chips in tires } \\
\text { (Michelin told them about the ability to put chips in tires that can signal on the dash when the } \\
\text { tire pressure is too low.) }\end{array}$ \\
\hline
\end{tabular}

It appears that many carriers are not aware of many of the technologies that are available nor are they aware of others using safety systems. Of any system available, the Eaton-VORAD equipment is the most familiar. This is not surprising due to the number of installed units in the field and their aggressive promotional program. 
Question 1C. Which of the 3 systems described are you familiar with?

Where: $\quad$ CWS/ACC $=$ Collision Warning System/Adaptive Cruise Control

RA\&C $=$ Roll Advisor and Controller

LDW = Lane Departure Warning

Note that some of the following answers conflict with the answers given by some participants in question 1B. The reason is unknown. It can easily be concluded that there is some knowledge of existing on-board safety technology systems but it is very "vague and fuzzy" in most carriers minds as to what is available or being developed.

\begin{tabular}{|c|l|}
\hline Carrier & \multicolumn{2}{|c|}{ Answer } \\
\hline $\mathbf{1}$ & CWS/ACC + LDW \\
\hline $\mathbf{2}$ & CWS/ACC + RA\&C + LDW (especially CWS/ACC) \\
\hline $\mathbf{3}$ & CWS/ACC + RA\&C + LDW (have not seen any of them in operation) \\
\hline $\mathbf{4}$ & CWS/ACC + RA\&C \\
\hline $\mathbf{5}$ & CWS/ACC + RA\&C + LDW (at least some familiarity) \\
\hline $\mathbf{6}$ & CWS/ACC + RA\&C + LDW \\
\hline $\mathbf{7}$ & CWS/ACC + RA\&C + LDW (but just a little about all of them) \\
\hline $\mathbf{8}$ & CWS/ACC + LDW + RA\&C (in that order) \\
\hline $\mathbf{9}$ & CWS/ACC \\
\hline $\mathbf{1 0}$ & None \\
\hline $\mathbf{1 1}$ & CWS/ACC + RA\&C + LDW \\
\hline $\mathbf{1 2}$ & CWS/ACC \\
\hline $\mathbf{1 4}$ & CWS/ACC \\
\hline $\mathbf{1 5}$ & None \\
\hline $\mathbf{1 6}$ & CWS/ACC \\
\hline $\mathbf{1 7}$ & CWS/ACC \\
\hline $\mathbf{1 8}$ & Not recorded \\
\hline $\mathbf{1 9}$ & Not recorded \\
\hline
\end{tabular}


2. Summary of impact of factors on a trucking company's decision to buy and use in-vehicle safety technologies (either original or retrofit equipment).

Relative Scale: $1=$ not important (NI) to $5=$ very important (VI)

Note: $\mathrm{NV}(\#)=$ No Vote (number)

\begin{tabular}{|c|c|c|c|c|c|}
\hline Factor & $1(\mathrm{NI})$ & 2 & 3 & 4 & $5(\mathrm{VI})$ \\
\hline $\begin{array}{l}\text { Cost to install and } \\
\text { maintain }\end{array}$ & & & $\mathbf{X}$ & $\mathbf{X X}$ & $\begin{array}{l}\text { XXXXXXXX } \\
\text { XXXXXXXX }\end{array}$ \\
\hline Cost to train drivers & $\mathbf{X}$ & XXXX & XXXXX & $\mathbf{X X}$ & $\overline{X X X X X X X}$ \\
\hline $\begin{array}{l}\text { Overall driver } \\
\text { satisfaction/reduced } \\
\text { turnover }\end{array}$ & & & XXXXX & $\begin{array}{c}\text { XXXXXXXX } \\
\text { XX }\end{array}$ & XXXXX \\
\hline $\begin{array}{l}\text { Driver acceptance of a } \\
\text { system }\end{array}$ & $\bar{X}$ & & XXXXXX & XXXXXXX & $\mathbf{X X X X X}$ \\
\hline $\begin{array}{l}\text { Accuracy and } \\
\text { reliability of the system }\end{array}$ & & & & $\mathbf{X}$ & $\begin{array}{c}\text { XXXXXXXX } \\
\text { XXXXXXXX } \\
\text { XX } \\
\end{array}$ \\
\hline $\begin{array}{l}\text { Effectiveness of a } \\
\text { system to improve } \\
\text { safety }\end{array}$ & NV(1) & & & $\mathbf{X X}$ & $\begin{array}{l}\text { XXXXXXXX } \\
\text { XXXXXXXX }\end{array}$ \\
\hline $\begin{array}{l}\text { Insurance company } \\
\text { requirement }\end{array}$ & NV(1) & $\mathbf{X X}$ & XXXXXX & $\mathbf{X X}$ & XXXXXXXX \\
\hline $\begin{array}{l}\text { Reduced insurance } \\
\text { premiums }\end{array}$ & NV(3) & & XXX & XXXXXX & XXXXXXX \\
\hline $\begin{array}{l}\text { Reduced accident- } \\
\text { related costs }\end{array}$ & NV(3) & & $\bar{X}$ & $\mathbf{X X X}$ & $\begin{array}{c}\mathrm{XXXXXXXX} \\
\text { XXXX }\end{array}$ \\
\hline Tax incentives & NV(1) & $\mathbf{X X X}$ & XXXX & XXXXX & XXXXXX \\
\hline Other (please specify) & & & & & $\begin{array}{c}\text { X (Good } \\
\text { Corporate } \\
\text { Citizen) } \\
\text { X (Federal } \\
\text { Requirement) }\end{array}$ \\
\hline
\end{tabular}




\section{Other comments captured when receiving answers to Question 2 follow:}

\begin{tabular}{|c|c|}
\hline Carrier & Comment \\
\hline 1 & $\begin{array}{l}\text { Safety technologies wouldn’t affect turnover in our company because we don't have a turnover } \\
\text { problem. But for companies where turnover is a problem, safety technologies would help. Driver } \\
\text { acceptance is important because they can kill you if you don’t get them to work with you. }\end{array}$ \\
\hline 2 & $\begin{array}{l}\text { Skeptical about intelligent systems because human factor is \#1 issue. Truck owners think machine } \\
\text { can’t do safety monitoring. It’s not reliable because driving safety is too complex for a lane tracking } \\
\text { device. Industry wide is very cost prohibitive to use safety systems. Intelligent systems will not } \\
\text { affect turnover of driver. }\end{array}$ \\
\hline 3 & $\begin{array}{l}\text { Driver acceptance is not an issue; put it in and they’ll use it. Biggest problem is cost; need to } \\
\text { convince upper management; must be reasonably priced. }\end{array}$ \\
\hline 4 & $\begin{array}{l}\text { Ins. co. requirement is not important unless they are offering a discount. Tax incentive is probably } \\
\text { the most important. }\end{array}$ \\
\hline 5 & $\begin{array}{l}\text { Must be real reliable. Need to see data of how it performs from carriers or industry and reduction in } \\
\text { accident levels, then would consider }\end{array}$ \\
\hline 6 & If made it a Federal requirement, we will do it (see other above) \\
\hline 7 & Tax incentives will never happen so ranked it very low. \\
\hline 8 & $\begin{array}{l}\text { Systems have to be cost-effective to yield benefit in accident reduction and costs, user friendly and } \\
\text { allow driver acceptance by easy education process. Multiple vehicle collisions are where the costs } \\
\text { and damages are and according to the Government, } 78 \% \text { of those accidents are the non-truck driver's } \\
\text { (i.e., car's) fault. Besides indictors only preclude certain events such as single vehicle events and } \\
\text { those are minor. }\end{array}$ \\
\hline 9 & Anything mechanical can fail especially if brand new. \\
\hline 10 & No comments \\
\hline 11 & No comments \\
\hline 12 & No comments \\
\hline 13 & No comments \\
\hline 14 & Don't want computer riding me. Still rely on myself. It's a machine and they break. \\
\hline 15 & Reliability concerns. Don’t want technology to interfere with driving. \\
\hline 16 & Don’t do well with reading. Don’t have eye-brain coordination. \\
\hline 17 & $\begin{array}{l}\text { Wants ability to turn off at times - VORAD (i.e., Chicago or construction zones). Worried data } \\
\text { would be used by enforcement/police/cops. }\end{array}$ \\
\hline 18 & Going down the road, someone cuts me off and systems could distract. \\
\hline 19 & $\begin{array}{l}\text { This technology could be expensive. It might be a distraction until adjusted. Could adapt to become } \\
\text { second nature. }\end{array}$ \\
\hline
\end{tabular}




\section{B-3. Drivers and Independent Owner-Operators}

Twenty drivers were surveyed to better understand their familiarity and opinions concerning IVI on-board safety systems. The interviews were performed on a one-on-one basis. A random sample of drivers was accessed at an interstate truckstop. A second interview process was done at a tank carrier company in Northern Ohio. The interviews took approximately 20 minutes and followed a structured interview format organized by an interview survey form (see Appendix A). The interviews attempted to gather information concerning:

- Driver profile

- Experience with IVI technology

- Training received on IVI systems in use

- Learning/training preference

- Attitudes regarding the use of IVI safety systems

- Open comments soliciting any suggestions to advance safety.

The results of the driver interviews are summarized in the following tables. 
Experience with Truck Safety Technologies

\begin{tabular}{|c|c|c|c|c|c|}
\hline Safety System Type & $\begin{array}{l}\text { Ever Used? } \\
\qquad / / N\end{array}$ & $\begin{array}{l}\text { Currently } \\
\text { Using? } \\
Y / N\end{array}$ & $\begin{array}{l}\text { Years/Months } \\
\text { of Experience? }\end{array}$ & $\begin{array}{l}\text { Willing to Try? } \\
\qquad \mathrm{Y} / \mathrm{N}\end{array}$ & $\begin{array}{l}\text { Usefulness? } \\
\text { Rank } 1^{\text {st }}, 2^{\text {nd }}, 3^{\text {rd }}\end{array}$ \\
\hline a) $\mathrm{ABS}$ & $\begin{array}{l}17 \text { Yes } \\
2 \mathrm{No}\end{array}$ & $\begin{array}{l}15 \mathrm{Yes} \\
4 \mathrm{No}\end{array}$ & Avg. 5 Years & $\begin{array}{l}\text { Of the drivers not } \\
\text { using ABS, most } \\
\text { said No. }\end{array}$ & Incomplete data \\
\hline $\begin{array}{l}\text { b) Electronic disc brakes - like ABS- } \\
\text { advanced braking system (ECBS) }\end{array}$ & $\begin{array}{l}2 \text { Yes } \\
17 \mathrm{No}\end{array}$ & $\begin{array}{l}1 \text { Yes } \\
19 \text { No }\end{array}$ & One trip & $\begin{array}{l}14 \text { Yes } \\
4 \text { No } \\
1 \text { Maybe }\end{array}$ & $\begin{array}{ll}1^{\text {st }} & 2 \\
2^{\text {nd }} & 3 \\
3^{\text {rd }} & 0 \\
\text { Don't know } & 1 \\
\end{array}$ \\
\hline c) In-Vehicle Navigation (GPS) & $\begin{array}{l}1 \text { Yes } \\
18 \text { No }\end{array}$ & $\begin{array}{l}1 \text { Yes } \\
18 \text { No }\end{array}$ & 1 Yes -6 weeks & $\begin{array}{l}17 \text { Yes } \\
2 \mathrm{No}\end{array}$ & $\begin{array}{ll}1^{\text {st }} & 5 \\
2^{\text {nd }} & 1 \\
3^{\text {rd }} & 2 \\
\end{array}$ \\
\hline $\begin{array}{l}\text { d) Lane Tracking/Lane Departure } \\
\text { Warning }\end{array}$ & $\begin{array}{l}0 \text { Yes } \\
19 \text { No }\end{array}$ & $\begin{array}{l}0 \text { Yes } \\
19 \text { No }\end{array}$ & --- & $\begin{array}{l}18 \text { Yes } \\
1 \text { No }\end{array}$ & $\begin{array}{ll}1^{\text {st }} & 6 \\
2^{\text {nd }} & 2 \\
3^{\text {rd }} & 4 \\
\end{array}$ \\
\hline e) Pre-Pass & $\begin{array}{l}8 \text { Yes } \\
11 \text { No }\end{array}$ & $\begin{array}{l}5 \text { Yes } \\
14 \text { No }\end{array}$ & Avg. 1.75 & $\begin{array}{l}11 \text { Yes } \\
4 \text { No } \\
4 \text { No Answer }\end{array}$ & $\begin{array}{ll}1^{\text {st }} & 2 \\
2^{\text {nd }} & 2 \\
3^{\text {rd }} & 3 \\
12 & \text { No Answer } \\
\end{array}$ \\
\hline f) Rollover advisory system & $\begin{array}{l}0 \text { Yes } \\
19 \text { No }\end{array}$ & $\begin{array}{l}0 \text { Yes } \\
19 \text { No }\end{array}$ & --- & $\begin{array}{l}18 \text { Yes } \\
1 \text { No }\end{array}$ & $\begin{array}{ll}1^{\text {st }} & 2 \\
2^{\text {nd }} & 2 \\
3^{\text {rd }} & 6 \\
\end{array}$ \\
\hline g) Rollover control system & $\begin{array}{l}0 \text { Yes } \\
19 \text { No }\end{array}$ & $\begin{array}{l}0 \text { Yes } \\
19 \text { No }\end{array}$ & --- & $\begin{array}{l}12 \text { Yes } \\
7 \mathrm{No}\end{array}$ & $\begin{array}{ll}1^{\text {st }} & 0 \\
2^{\text {nd }} & 0 \\
3^{\text {rd }} & 4 \\
15 & \text { No Answer } \\
\end{array}$ \\
\hline $\begin{array}{l}\text { h) Smart-Cruise-Fixed Following } \\
\text { Distance-adaptive cruise control }\end{array}$ & $\begin{array}{l}0 \text { Yes } \\
19 \text { No }\end{array}$ & $\begin{array}{l}0 \text { Yes } \\
19 \text { No }\end{array}$ & --- & $\begin{array}{l}14 \text { Yes } \\
5 \text { No }\end{array}$ & $\begin{array}{ll}1^{\text {st }} & 1 \\
2^{\text {nd }} & 2 \\
3^{\text {rd }} & 3 \\
13 & \text { No Answer } \\
\end{array}$ \\
\hline $\begin{array}{l}\text { i) [VORAD] forward-radar following } \\
\text { distance-noise/visual alerts }\end{array}$ & $\begin{array}{l}1 \text { Yes } \\
19 \text { No }\end{array}$ & $\begin{array}{l}0 \text { Yes } \\
19 \text { No }\end{array}$ & 1 Yes -3 Months & $\begin{array}{l}18 \text { Yes } \\
1 \text { No }\end{array}$ & $\begin{array}{ll}1^{\text {st }} & 1 \\
2^{\text {nd }} & 1 \\
3^{\text {rd }} & 1 \\
16 & \text { No Answer }\end{array}$ \\
\hline $\begin{array}{l}\text { j) Warning of blind spots - side- } \\
\text { looking radar }\end{array}$ & $\begin{array}{l}1 \text { Yes } \\
18 \mathrm{No}\end{array}$ & $\begin{array}{l}0 \text { Yes } \\
19 \text { No }\end{array}$ & 1 Yes -3 Months & $\begin{array}{l}19 \text { Yes } \\
0 \text { No }\end{array}$ & $\begin{array}{ll}1^{\text {st }} & 6 \\
2^{\text {nd }} & 6 \\
3^{\text {rd }} & 1 \\
6 \text { No Answer } \\
\end{array}$ \\
\hline
\end{tabular}


From the preceding table, drivers had experience using ABS systems and the Pre-Pass.

However, drivers had little experience or knowledge of other IVI safety systems. The interviews did indicate they were, for the most part, willing to try new systems. When asked usefulness, most had difficulty answering since they had no experience or knowledge of the systems.

\section{Training the Use of Truck Safety Systems (where applicable)}

\begin{tabular}{|l|l|l|}
\hline Safety System Type & \multicolumn{1}{c|}{$\begin{array}{c}\text { Ever Received } \\
\text { Training? } \\
\text { Y / N }\end{array}$} & $\begin{array}{c}\text { Effectiveness of } \\
\text { Training? } \\
1-2-3-4-5\end{array}$ \\
\hline m. ABS & 1 Yes & 2 \\
\hline n. Electronic disc brakes - like ABS-advanced braking system (ECBS) & & \\
\hline o. In-Vehicle Navigation (GPS) & & \\
\hline p. Lane Tracking/Lane Departure Warning & & \\
\hline q. Pre-Pass & & \\
\hline r. Rollover advisory system & & $1-$ told us to try it \\
\hline s. Rollover control system & 1 Yes & 1 \\
\hline t. $\quad$ Smart-Cruise-Fixed Following Distance-adaptive cruise control & 1 Yes & 1 \\
\hline u. $\quad$ VORAD] forward-radar following distance-noise/visual alerts & 1 Yes & \\
\hline v. $\quad$ Warning of blind spots - side-looking radar & & \\
\hline
\end{tabular}

Very little training as shown in the table above was given for any of the systems that drivers had been given the opportunity to use. Even when training was provided, the drivers felt it was poor. 


\section{Learning / Training Preference (Rank 1-2-3. W refers to Worse Way)}

\begin{tabular}{|c|c|c|c|}
\hline Learning/Training Method & $\begin{array}{c}\text { Rank Top Three } \\
\text { (how you want to } \\
\text { hear about it) } \\
1-2-3-W\end{array}$ & $\begin{array}{c}\text { Rank Top Three } \\
\text { (ways to learn to } \\
\text { use it) } \\
1-2-3-W\end{array}$ & $\begin{array}{l}\text { Comments/what } \\
\text { system? }\end{array}$ \\
\hline o. Actual road experience training? & --- & $\begin{array}{rr}1-5 & 2-2 \\
3-5 & W-0 \\
\end{array}$ & \\
\hline p. CB? & $\begin{array}{rr}1-0 & 2-1 \\
3-0 & W-2 \\
\end{array}$ & $\begin{array}{rr}1-0 & 2-0 \\
3-0 & W-1 \\
\end{array}$ & \\
\hline q. Formal classroom/company orientation training? & $\begin{array}{rr}1-4 & 2-2 \\
3-3 & W-1\end{array}$ & $\begin{array}{rr}1-9 & 2-2 \\
3-3 & W-0\end{array}$ & With lunch \\
\hline r. Government mandate? & $\begin{array}{rr}1-0 & 2-0 \\
3-0 & W-8\end{array}$ & $\begin{array}{rr}1-0 & 2-0 \\
3-0 & W-3\end{array}$ & \\
\hline s. Internet/e-mail/Web - computer & $\begin{array}{rr}1-0 & 2-0 \\
3-0 & W-0 \\
\end{array}$ & $\begin{array}{rr}1-0 & 2-0 \\
3-0 & W-0 \\
\end{array}$ & \\
\hline $\begin{array}{l}\text { t. Magazines (i.e., Heavy-Duty Trucking, OTR, Owner- } \\
\text { Operator) }\end{array}$ & $\begin{array}{rr}1-4 & 2-6 \\
3-5 & W-0 \\
\end{array}$ & $\begin{array}{rr}1-0 & 2-1 \\
3-3 & W-0 \\
\end{array}$ & $\begin{array}{l}\text { Overdrive, Landline, } \\
\text { Road King, Fleet } \\
\text { Maintenance, free }\end{array}$ \\
\hline u. Message over company communication system? & $\begin{array}{lr}1-1 & 2-2 \\
3-1 & W-0\end{array}$ & $\begin{array}{rr}1-0 & 2-0 \\
3-0 & W-0\end{array}$ & \\
\hline v. On-site orientations or ride-alongs? & $\begin{array}{rr}1-0 & 2-0 \\
3-0 & W-0\end{array}$ & $\begin{array}{rr}1-0 & 2-1 \\
3-0 & W-0\end{array}$ & \\
\hline w. Read manuals? & $\begin{array}{rr}1-0 & 2-0 \\
3-0 & W-1 \\
\end{array}$ & $\begin{array}{rr}1-0 & 2-2 \\
3-3 & W-0 \\
\end{array}$ & \\
\hline x. Simulator or test track trials? & $\begin{array}{rr}1-0 & 2-0 \\
3-0 & W-0\end{array}$ & $\begin{array}{rr}1-0 & 2-0 \\
3-3 & W-0\end{array}$ & \\
\hline y. Talk with other drivers? & $\begin{array}{rr}-2 & 2-1 \\
3-1 & W-2 \\
\end{array}$ & $\begin{array}{rr}1-0 & 2-0 \\
3-0 & W-0 \\
\end{array}$ & \\
\hline z. Hands on? & $\begin{array}{rr}1-4 & 2-2 \\
3-1 & W-1 \\
\end{array}$ & $\begin{array}{lr}1-6 & 2-6 \\
3-3 & W-0\end{array}$ & \\
\hline aa. Truck shows? & $\begin{array}{rr}1-0 & 2-1 \\
3-0 & W-0 \\
\end{array}$ & $\begin{array}{rr}1-0 & 2-0 \\
3-1 & W-0\end{array}$ & \\
\hline $\begin{array}{c}\text { bb. Other? (truckstops, demos, signs/billboards, wife(?), } \\
\text { instructor, truck dealer, terminal demo) }\end{array}$ & $\begin{array}{lr}1-4 & 2-3 \\
3-5 & W-6\end{array}$ & $\begin{array}{rr}1-0 & 2-6 \\
3-2 & W-8\end{array}$ & \\
\hline
\end{tabular}

In ranking how drivers want to hear about new technologies, they chose magazines, truckstops, demos and billboards as the best ways. It is interesting to note the Government mandate was rated the worse. This confirms how drivers feel about Government mandating.

Concerning how drivers want to learn to use technologies, they prefer classroom training followed by actual road experience and hands on. 


\section{Driver Attitudes Regarding the Use of Truck Safety Systems in General}

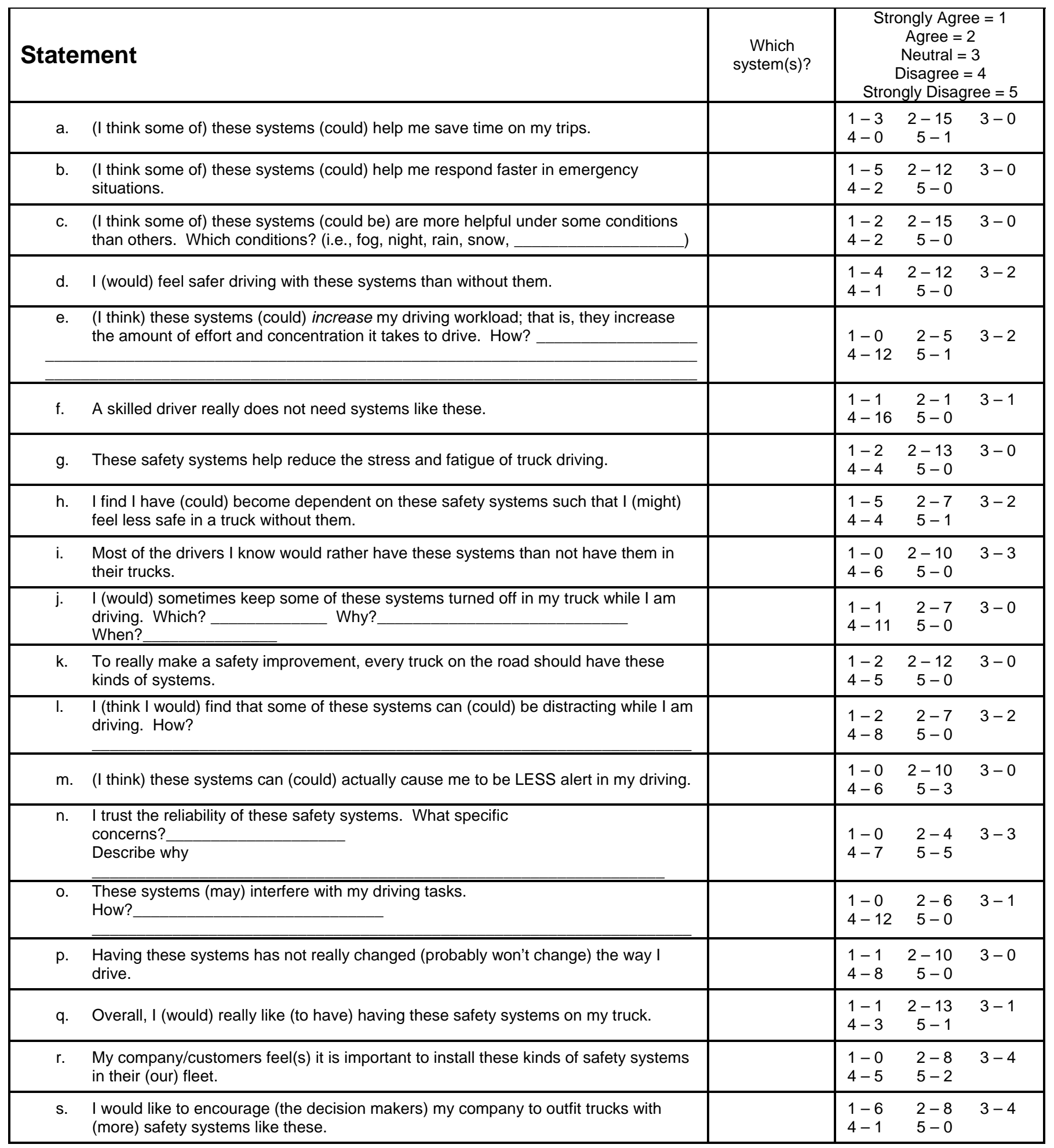


From the inputs received in this table and general responses documented:

A. Most drivers were positive about the use of on-board safety technologies. They expressed a desire to have the technologies but many said that they would probably turn them off as times. They thought they would not increase workload and all drivers, both experienced and inexperienced, could benefit from use of the technologies.

\section{Open comments from drivers about ways to advance safety}

- Suggestions for making further safety improvements:

o Driving licensing for cars should include understanding trucks

o Allow automobile drivers the experience of riding in a truck

o Include automatic transmissions in all trucks

o Have longer more comprehensive truck driving training programs

o Things to avoid sleep impairment. Fresh air circulation

o Better license screening

o Smith System training for every driver including cars

o Get more of the "wanna-be" truckers off the road

0 Better screening of drivers before they are hired

0 Raise age limit for drivers

o Work the bugs out of any equipment before you introduce them into the market place

- Other technologies that he/she would like on their truck that they do not currently have:

o GPS

o Blindspot sensors

o VORAD collision warning system

o Route guidance

o Lane tracking

o Rollover prevention systems

[Note the truckers had difficulty with this question because they are not cognizant of what is available]

- Ways to introduce new safety technology:

o $\quad$ First must gain upper management support

o Provide it for trial runs. Give drives the chance to use it.

o Demonstrate at truck shows

o Have equipment available for show and demonstrations at truckstops

o Publicize in magazines to gain familiarity

- Crashes/Violations in past 3 years:

o Ranged from 2 to 8 million miles

o A few speeding tickets but only 4 among the 19 drivers 
- Other Comments:

o "this is a good thing"

o Concerned about expense

o Need to communicate for emergencies

o Could help drivers (new drivers especially) reduce stress

o Could really help with rollovers in triple trailers

o Cautious. Don't really trust electronics

o It's all good technology and all companies should have them. Depends on dollars. 


\section{B-4. Insurance Companies}

The interview process for insurance companies differed from other stakeholders. The insurance companies are not manufacturers, buyers, or users of the IVI technology. However, their opinions are of interest because one of the larger benefits from the use of the technology and subsequent reduction in crashes is the desirable reduction in insurance costs. Insurance for carriers and independent owner-operators represents significant costs.

Five insurance companies were interviewed. The following summarizes the information obtained:

\section{Question 1. What in-vehicle safety technologies or systems are you aware of?}

A Collision warning with adaptive cruise control, lane departure warning systems, and auto logger for the driver.

B None.

C Collision warning with adaptive cruise control, vaguely aware of lane departure warning systems, and WorldCom GPS.

D Collision warning with adaptive cruise control, lane departure warning systems, and automatic loggers

E Most aware of collision warning with adaptive cruise control. Also, discussed human factors issues and eye tracking to detect fatigue and alertness.

Question 2. The three technologies from the field operational tests were mentioned and the insurance companies were asked if they were familiar with the technologies.

A Collision Warning with Adaptive Cruise Control- Yes Lane Departure Warning System- $\quad$ Yes Rollover Advisor and Controller- $\quad$ No

B Collision Warning with Adaptive Cruise Control- No Lane Departure Warning System- No Rollover Advisor and Controller- $\quad$ No

C Collision Warning with Adaptive Cruise Control- Yes Lane Departure Warning System- $\quad$ Yes - have heard of it Rollover Advisor and Controller- $\quad$ No 
D Collision Warning with Adaptive Cruise Control- Yes

Lane Departure Warning System-

Yes - have heard of it

Rollover Advisor and Controller-

No

E Collision Warning with Adaptive Cruise Control- Yes Lane Departure Warning System-

Yes

Rollover Advisor and Controller-

Yes

Question 3. What factors impact the decisions of carriers to buy and use on-board safety technologies (either retrofit or as original truck equipment): $(1=$ not important; 5 = very important)

\begin{tabular}{|c|c|c|c|c|c|}
\hline & 1 & 2 & 3 & 4 & 5 \\
\hline Cost to install and maintain & & & $\mathbf{A}$ & & B, C, D, E \\
\hline Cost to train drivers in use & D & $\mathbf{A}$ & & & \\
\hline $\begin{array}{l}\text { Overall driver } \\
\text { satisfaction/reduced } \\
\text { turnover }\end{array}$ & & $\mathbf{E}$ & $\mathbf{A}$ & & \\
\hline $\begin{array}{l}\text { Driver acceptance of a } \\
\text { system }\end{array}$ & & & & & $\mathbf{A}, \mathbf{E}$ \\
\hline $\begin{array}{l}\text { Accuracy and reliability of a } \\
\text { system }\end{array}$ & & & & C, D & $\mathbf{A}, \mathbf{E}$ \\
\hline $\begin{array}{l}\text { Effectiveness of a system in } \\
\text { improving safety }\end{array}$ & & & & A & B, C, D \\
\hline $\begin{array}{l}\text { Insurance company } \\
\text { requirement }\end{array}$ & $\mathbf{D}, \mathbf{E}$ & $\mathbf{B}$ & & A & \\
\hline $\begin{array}{l}\text { Reduced insurance } \\
\text { premiums }\end{array}$ & $\mathbf{E}$ & & & A & C, D \\
\hline $\begin{array}{l}\text { Reduced accident-related } \\
\text { costs }\end{array}$ & & & & $\mathbf{A}$ & B, C, D \\
\hline Tax incentives & & $\mathbf{A}$ & & B, C & \\
\hline
\end{tabular}




\section{Appendix C:}

\section{Interview Participants}




\section{Carriers}

Bob Evans Farms Inc.

3776 South High Street

Columbus, $\mathrm{OH} 43207$

(614) 491-2225

Power Units: 26

Drivers: 37

Private, Interstate, Handle General Freight, Meat, Refrigerated Food

No Hazmat Status

Dutch Maid Logistics Inc.

4118 State Route $103 \mathrm{~S}$

Willard, $\mathrm{OH}$ 44890-9623

(419) 935-0136

P O Box 365

Willard, OH 44890-0365

Power Units: 47

Drivers: 53

Authorized For Hire, Interstate, Handle Fresh Produce, Refrigerated Food, Paint-Related

No Hazmat Status

Jet Express Inc.

4518 Webster St

Montgomery, OH 45414-4940

(937) 274-7033

Power Units: 288

Drivers: 315

Authorized For Hire; Interstate, Handle General Freight, Automotive Parts

No Hazmat Status

The New Bakery Co of Ohio Inc.

750 Airport Road

Zanesville, $\mathrm{OH}$ 43701-9694

(740) 454-6876

Power Units: 44

Drivers: 105

Private, Interstate, Handle Commodities, Dry Bulk, Refrigerated Food 
R \& L Transfer Inc.

600 Gillam Rd

Wilmington, $\mathrm{OH} 45177$

(937) 382-1494

P O Box 271

Wilmington, $\mathrm{OH} 45177$

Power Units: 2,263

Drivers: 1,234

Authorized For Hire, Interstate, Handle General Freight, Household Goods, Chemicals, Commodities Dry Bulk

Hazmat

\section{Arctic Express Inc.}

4277 Lyman Drive

Hilliard, $\mathrm{OH} 43026$

(614) 876-4008

P O Box 129

Hilliard, $\mathrm{OH} 43026$

Power Units: 491

Drivers: 484

Authorized For Hire, Interstate, Handle General Freight, Fresh Produce, Chemicals, Refrigerated Food

Hazmat

\section{Wooster Motor Ways Inc.}

3501 West Old Lincoln Way

Wooster, $\mathrm{OH} 44691$

(330) 264-7690

P O Box 19

Wooster, OH 44691-0019

Power Units: 180

Drivers: 155

Authorized For Hire, Interstate, Handle General Freight, Metal (Sheets, Coils, Rolls), Building

Materials, Liquids, Gases, Chemicals, Commodities, Dry Bulk, Paper Products

Hazmat

\section{The Best Transfer Company}

5550 Este Ave

Cincinnati, OH 45232

(513) 242-3456

Power Units: 541

Drivers: 501

Authorized For Hire, Interstate, Handle General Freight, Metal (Sheets, Coils, Rolls), Drive/Towaway, Lumber (Logs, Poles, Beams), Machinery, Large Objects, Construction No Hazmat Status 
Mc Tank Transport Inc.

10134 Mosteller Lane

West Chester, OH 45069

(513) 771-8667

Power Units: 58

Drivers: 55

Authorized For Hire, Interstate, Liquids, Gases, Chemicals

Hazmat

Yellow Transportation Inc.

10990 Roe Ave

Overland Park KS 66211

(913) 344-3000

P O Box 7270

Overland Park, KS 66207

Power Units: 8,392

Drivers: 13,123

Authorized For Hire, Interstate, Interstate Hazmat, Handle General Freight, Intermodal

Continental, Chemicals

Hazmat

\section{Roadway Express Inc.}

1077 Gorge Blvd

Akron, OH 44310

(330) 384-1717

P O Box 471

Akron, $\mathrm{OH}$ 44309-0471

Power Units: 9,737

Drivers: 13,146

Authorized For Hire, Interstate, Interstate, Handle General Freight, Household Goods, Metal

(Sheets, Coils, Rolls), Building Materials, Machinery, Large Objects, Liquids/Gases, Intermodal

Continental, Oilfield Equipment, Chemicals, Beverages, Paper Products

Hazmat

USF Holland Inc.

750 E 40th St

Holland, MI 49423

(616) 395-5000

Power Units: 4,405

Drivers: 8,000

Authorized For Hire, Interstate, Interstate Hazmat, Handle General Freight, Liquids/Gases,

Chemicals

Hazmat 


\section{CRST Van Expedited Inc.}

3930 16th Avenue, S W

Cedar Rapids, IA 52404

(319) 396-4400

Mailing Address: P O Box 68

Cedar Rapids, IA 52406

Power Units: 1,321

Drivers: 2,388

Authorized For Hire, Interstate, Handle General Freight, Household Goods, Metal (Sheets, Coils, Rolls), Building Materials, Liquids/Gases, U.S. Mail, Chemicals, Commodities, Dry Bulk, Beverages, Paper Products, Agriculture/Farm Supplies

Hazmat

\section{Swift Transportation Co Inc.}

Physical Address: 2200 South 75th Avenue

Phoenix, AZ 85043

(602) 269-9700

P O Box 29243

Phoenix, AZ 85038-9243

Power Units: 10,550

Drivers: 11,324

Authorized For Hire, Interstate, Handle General Freight, Metal (Sheets, Coils, Rolls), Motor

Vehicles, Lumber (Logs, Poles, Beams), Building Materials, Machinery, Large Objects, Fresh

Produce, Liquids, Gases, Intermodal Continental, Grain, Feed Hay, Meat, Chemicals, Commodities, Dry Bulk, Refrigerated Food, Beverages, Paper Products, Construction

Hazmat

\section{Watkins Motor Lines Inc.}

1144 West Griffin Rd

Lakeland, FL 33804-2444

(941) 872-3841

Mailing Address: P O Box 95002

Lakeland, FL 33804-5002

Power Units: 3,245

Drivers: 4,889

Authorized For Hire, Interstate, Handle General Freight

No Hazmat Status 
The Kroger Co.

1014 Vine Street

Cincinnati, OH 45202

(513) 782-3763

Power Units: 273

Drivers: 293

Authorized For Hire, Private (Property), Interstate, Handle Fresh Produce, Refrigerated Food, Beverages, Supermarket Food

No Hazmat Status

FedEx Ground Package System Inc.

1000 FedEx Dr

Coraopolis, PA 15108

(412) 269-1000

P O Box 108

Pittsburgh, PA 15230-0108

Power Units: 11,948

Drivers: 12,081

Authorized For Hire, Interstate, Interstate Hazmat, Handle General Freight, Small Packages

Hazmat

United Parcel Service Inc.

643 West 43rd St

New York, NY 10036

(404) 828-6338

55 Glen lake Parkway Northeast

Atlanta, GA 30328

Power Units: 44,852

Drivers: 45,384

Authorized For Hire, Interstate, Handle General Freight

No Hazmat Status

\section{Insurance Companies and Brokers}

Liberty Mutual Insurance Company

71 Frank land Road

Hopkinton, MA 01748

Great West Casualty Co.

1100 West $29^{\text {th }}$ Street

South Sioux City, NE 68776

Hailer, Fryer and Coon

231 Salina Meadows Parkway

P O Box 4743

Syracuse, NY 13221-474 
St. Paul Companies

Minneapolis, MN

Marsh Inc.

59 Park Place

Appleton, WI 


\section{Other}

American Trucking Associations

2200 Mill Road

Alexandria, VA 22314-4677

(703) 838-1700

Smith System Driver Improvement Institute, Inc.

2201 Brookhollow Plaza Drive, Suite 200

Arlington, TX 76006

(817) 652-6969

(817) 652-1942

New York State Motor Truck Association

828 Washington Avenue

Albany, NY 12203-1622

(518) 458-9696

Fax: (518) 458-2525

\section{Manufacturers}

Navistar International (OEM)

4201 Winfield Road, P O Box 1488

Warrenville, IL 60555

(630) 753-5000

Fax: (630) 753-2303

Oshkosh Truck Corporation (OEM)

2307 Oregon Street

Oshkosh, WI 54902

(920) 235-9151

Fax: (920) 233-9314

PACCAR Tech Center (It Supports Peterbilt and Kenworth) (OEM)

Bldg., 777 106th Avenue, NE

Bellevue, WA 98004

(425) 468-7400

(425) 468-8216

\section{Freightliner/Sterling (OEM)}

4747 N. Channel Avenue

Portland, OR 97217

(503) 745-8000

(503) 745-8921 
International Truck and Engine (OEM)

3033 Wayne Trace

Fort Wayne, IN 46806-3968

P O Box 535

Fort Wayne, IN 46801-0535

(260) 461-1930

Volvo Truck, North America (OEM)

7900 National Service Road

Greensboro, NC 27402-5115

Meritor WABCO Vehicle Control Systems (Vendor)

3331 W Big Beaver Road

Troy, MI 48084-2804

Bendix (Vendor)

901 Cleveland Street

Elyria, OH 44035-4153

(440) 329-9000

TRW (Vendor)

1900 Richmond Road

Cleveland, OH 44124-2760

(216) 291-7000

Fax: (216) 291-7629 


\section{Appendix D:}

\section{Workshop Summary}




\title{
FMCSA IVI Workshop on On-board Safety Technology Deployment in Commercial Motor Vehicles
}

\author{
Battelle \\ 901 D St., SW, Suite 900 \\ Conference Rooms A/B \\ Washington, DC \\ August 7, 2003

\section{Summary of Workshop and Discussion}

The workshop began with Mr. John Allen (Battelle) welcoming everyone to the facility and introducing Ms. Amy Houser (FMCSA). Ms. Houser presented a brief overview of the project history and objectives (slides 1-8 of attachment) and turned the workshop over to Mr. Jerry Pittenger (Battelle), who functioned as facilitator for the discussion. A list of all workshop participants is attached.

The goal of the workshop was to acquire expert input from motor vehicle stakeholders (manufacturers, carriers, drivers, law enforcement, insurance companies, academia, and selected professional societies) on their views and perceptions of the improved Meritor WABCO rollover advisor and controller (RA\&C) with extended controller functionality. Input included where the roll technology can be effective, what extent benefits might be realized, and what might be done to gain stakeholder acceptance from their individual points of view.

\section{History/Background: Ms. Amy Houser and Mr. Jerry Pittenger}

The FMCSA initiated the evaluation and deployment of on-board safety technology for commercial vehicles as part of its Intelligent Vehicle Initiative (IVI) under the USDOT Intelligent Transportation Systems (ITS) program. Under the IVI program, three field operational tests (FOTs) of crash avoidance technologies were initiated and are at various stages of completion: Collision Warning System and Adaptive Cruise Control (Volvo FOT), the Rollover Advisor and Controller (Freightliner FOT), and the Lane Departure Warning Device (Mack FOT). Both the Volvo and Mack FOTs are scheduled for completion in 2005. The Freightliner FOT is complete.

Since the only FOT completed is the Freightliner RA\&C, the purpose of this workshop was to obtain input, feedback, and information from stakeholders that will assist in developing a deployment strategy for that technology. The Freightliner FOT was completed in 2002; however, during the data collection phase of the FOT, the vendor, Meritor WABCO, made significant improvements to the safety system. The improvements centered on a better algorithm to estimate the weight and center of gravity of the load and the application of the foundation brakes when a serious rollover condition is detected. 


\section{The RA\&C Technology and Freightliner FOT Evaluation Results: Mr. Alan Korn and Mr. Doug Pape}

Mr. Alan Korn (Meritor WABCO) presented an overview of the RA\&C technology that was the focus of the Freightliner FOT (a copy was provided in the workshop notebook and is attached). It was noted that the RA\&C was evaluated for the tractor and tank trailer combination only. He discussed the addition of an improved controller into the system and presented detailed schematics of the operation of the system - the components, the input required to trigger the controller, and a video of the track test showing the rollover event without the improved RA\&C. The video presentation provided convincing evidence of the benefit this technology could have on reducing rollover for combination vehicles. A question was asked on the use of the RA\&C if the ABS failed. The response was that it won't work under those conditions. It was also noted by Mr. Korn that the RA\&C system is effective only on roadways that allow for a dry pavement coefficient of friction. The system is less effective in rain, snow, and ice where lateral movement does not cause a lateral roll moment. Under these conditions, the vehicle tends to slide rather than roll. It was also noted that the improved RA\&C had not been tested beyond the test track.

Mr. Doug Pape (Battelle) provided an overview of the Freightliner FOT and presented the results of the benefit-cost analysis (BCA) for reducing truck crashes and fatalities. Mr. Pape noted that Freightliner did not use the improved RA\&C during any part of the FOT. He then explained the procedure used to develop a simulation model to evaluate the effectiveness of the improved RA\&C. A comparison between the FOT version and the Meritor WABCO improved version was made.

It should be noted that the presentation and discussion time needed by Mr. Pape and Mr. Korn exceeded the allocation by nearly 45 minutes. It became evident quickly that several people on the expert panel were not aware of the Freightliner FOT or the RA\&C. This was both surprising and eye-opening to the project team. It highlighted the fact that there may be a need for better outreach and awareness programs for the FOTs, as well as IVI safety technologies.

\section{Workshop Discussion: Mr. Jerry Pittenger - Facilitator}

The remainder of the workshop focused on answering six questions (attached) that were carefully selected prior to the workshop. It was noted that the expert panel was there to provide input only if questions were raised that required their responses.

The expert panel was given a set of worksheets to document/communicate their inputs to each question. This provided Battelle a way to analyze answers to the questions by stakeholder. For example, the premise is that the answer given by one stakeholder (i.e., driver) might be different than the answer given by another stakeholder (i.e., carrier). 
The following summarizes the expert panel discussion for each question addressed ${ }^{20}$ :

\title{
Question 1. a.) What conditions/characteristics/factors do you think impact the effectiveness of the RA\&C to either mitigate or reduce crash severity?
}

\author{
b.) How effective is the $R A \& C$ in reducing the likelihood of $1^{\text {st }}, 2^{\text {nd }}$, and 3 rd \\ order impacts for the conditions/characteristics factors identified? ${ }^{21}$
}

\section{Driver Profile}

The group was split as to the impact of driver experience on the effectiveness of the RA\&C. ${ }^{22}$ All were positive that the system would help both the experienced and the inexperienced driver. However, some thought the system would be more effective to reduce crashes for the inexperienced driver. The drivers present were positive about the usefulness of the RA\&C and the idea of improving their safety and reducing crashes regardless of the driver skill level. The expert panel thought that a combination tractor-trailer that is not a tanker would also benefit. For example, a box trailer is loaded at a terminal and the worker loading the trailer is not concerned with balancing the load. This can result in an unstable load that could shift during transport or would affect the driver handling of the combination.

The discussion of driver experience as a factor in the effectiveness of the RA\&C identified other important points and issues. One issue that was raised was the use of the data that would be produced by the system - number of warnings a driver received during a trip. From the perspective of the drivers, the data should be used to commend or reward good driving and to determine which drivers might require additional training or monitoring - a feedback mechanism. One comment was that this might give drivers a false sense of security and encourage them to test the limits. Another commenter responded that this was not an issue based on his experience with drivers.

The second factor under driver profile discussed was driver familiarity with the technology. In this regard, it was noted that insurance industry research is pending publication that indicates drivers are receptive to the use of technology, provided they are given training in its use in advance. A point was made that the RA\&C alone would not be effective, as drivers might have difficulty trusting the accuracy of the messages. A suggestion was made that FMCSA should include the RA\&C algorithms in simulator training that currently is being developed.

Other driver characteristics that might influence the effectiveness of the RA\&C include: personality, propensity to take risks, attitude, performance history, physical condition (fatigue, medication), and number of distractions in the cab. A consensus was the number of distractions, with the addition of on-board technologies, would need to be kept to a minimum.

\footnotetext{
${ }^{20}$ In the workshop, the expert panel had many questions about the RA\&C. These discussions reduced the time that could be spent on the six questions. Only questions 1,5 , and 6 were covered in detail.

${ }^{21}$ Part b. of question 1 was abandoned. It was creating confusion and the stakeholders clearly did not understand the definitions given for $1^{\text {st }}, 2^{\text {nd }}$, and $3^{\text {rd }}$ orders of effectiveness.

${ }^{22}$ The RA\&C during the question-answer part of the workshop referred only to the improved RA\&C.
} 
[The worksheet mark-up by participants indicates 9 of 14 felt driver experience could be a factor and 11 of 14 felt driver familiarity with the technology could be a factor.]

\section{$\underline{\text { Road Characteristics }}$}

Road characteristics discussed included mountainous terrain, ramps, freeways-urban vs. freeways-rural, and non-freeways-urban vs. non-freeways-rural.

The question was asked if the RA\&C recalculates the mass in the equation for the effect of mountainous terrain resulting in steep grades (uphill and downhill). The response was that it is constantly recalculating mass, but not under that scenario.

The effectiveness of the RA\&C in mitigating or reducing rollovers on mountainous roads and ramps was positive to the majority of participants. Whether or not the road was a freeway or non-freeway in urban or rural areas appeared to be less of a factor. One comment was made that curves occur on any highway system and the potential is there for rollover whether rural or urban. Another comment was that shoulders in rural areas are less forgiving, narrow, and soft and could result in rollover that could not be prevented by the RA\&C. Some believe the type of road does not matter as the driver behavior would change to adapt. In urban areas, the driver might need to make sudden moves to avoid hitting a vehicle that may have cut across his path - a real-life example was cited by one of the drivers present that did not result in a rollover but highlights the potential.

[The worksheet mark-up by participants indicates: (1) 13 of 15 felt the system could be effective on mountainous roads, (2) 15 of 15 felt the system could be effective on ramps, (3) 12 of 15 felt the system could be effective on urban freeways, (4) 10 of 14 felt the system could be effective on rural freeways, (5) 9 of 14 felt the system could be effective on urban non-freeways, and (6) 13 of 14 felt the system could be effective on rural non-freeways.]

\section{$\underline{\text { Climate Control }}$}

Climatic conditions discussed included snow and ice, rain, fog, and wind.

In general, the consensus of the group was that weather-related factors overshadow the effectiveness issue, as drivers tend to be more cautious under adverse climatic conditions. Also, snow, ice, and rain reduce the coefficient of friction (as noted by Mr. Korn earlier in the morning) and the vehicle will slide rather than roll under these conditions. Therefore, the group felt the system would be less effective in snow, rain, and ice. Likewise, the group felt that the system would not be very effective in windy conditions. The effect of wind on how trucks are driven and the impact on trailer sway is independent of the RA\&C.

However, the group did feel the system could be very effective in fog. This makes intuitive sense since drivers may enter curves and ramps too fast since they can not see far ahead of them.

[The worksheet mark-up by participants indicates that: (1) 10 out of 13 felt the system would not be as effective in snow and ice; (2) 9 out of 13 felt the system would not be as effective in 
rain; (3) 9 out of 13 felt the system would not be as effective in windy conditions. However, 13 of 13 felt the system would be effective in fog.]

\section{$\underline{\text { Carrier Profile }}$}

The carrier profiles discussed included interstate vs. intrastate, long haul vs. short haul, and large vs. small.

After some discussion on the operational differences between the carrier types, the type commodities, exposure to ramps, and potential for rollover, the consensus of the group was that carrier profile was not a factor - all carrier types can benefit from the RA\&C.

[The worksheet mark-up by participants indicates that, on all factors, only 3 out of 80 felt that the RA\&C would not be effective in regard to carrier profile classifications.]

\section{Type of Truck}

The types of trucks discussed included tractor-tank trailer, tractor-trailer, and straight truck. Potential problems with load shifts in tractor-trailers were mentioned that might affect the stability of these vehicles and their propensity for rollovers.

There was a clear consensus of opinion that the RA\&C would benefit the tractor-tank trailer combination most (13 out of 13 votes), followed closely by the tractor-trailer (11 definitely and 2 maybe votes). The opinion on the straight truck seemed to be less definitive but still positive that the RA\&C would be effective (4 definitely, 6 maybe, and 3 no votes).

Question 5. What things do you think motivate:

a.) OEMs/vendors to develop and manufacture IVI on-board technology?

b.) Carriers and independent owner-operators to buy IVI on-board technology?

c.) Drivers to use IVI on-board technology?

Question 6. a.) Considering the motivating factors identified in Question 5, what ideas do you have that might accelerate:

- Manufacture by OEMs and vendors?

- Purchase by carriers and independent owner-operators?

- Use by drivers?

b.) What risks might be encountered in any effort to accelerate the introduction and acceptance of on-board safety technologies?

c.) How can we best evaluate the user acceptance by carriers and drivers of an on-board safety technology?

d.) How can we gather data on a large population of carriers and drivers in a cost-effective manner? 
In the interest of time, Questions 5 and 6 were discussed after Question 1. A summary of the discussions by the expert panel follows:

Vendors (tiered suppliers) are motivated to develop and market technology for one or more of the following reasons:

- market opportunity,

- major customer request,

- competition,

- first to market (pull market),

- regulation, and

- $\quad$ sometimes a push market (if they know they have a good idea).

OEMs are motivated to manufacture a vehicle with technology by one or more of the following reasons:

- customer demand and willingness to pay a price that allows for profit,

- competitive advantage,

- desire for safety (need safety for image),

- build customer base,

- politically correct thing to do,

- $\quad$ payback for adding technology, and

- reduce liability or risk factors.

Carriers are motivated to purchase the technology for one or more of the following reasons:

- contractual requirements,

- $\quad$ need (to correct a problem area based on experience),

- improve bottom line,

- reduce risk,

- positive cost/benefit ratio,

- driver morale,

- aid in driver training, behavior modification (reduction of accidents),

- absolve the driver from blame with data from system,

- insurance impact (ROI, insurance benefit probably will not be seen for years until proof of value with crash data), controlled tests of equipment are needed, results of FOT to improve safety need to be made known to insurance companies,

- fleet replacement (add to new equipment as replace old, no retrofit), and

- industry image.

Drivers are motivated to use the technology for one or more of the following reasons:

- safe driving results in reward (recognition or dollars),

- recognize the value or benefits through education, training, and awareness (suggested the video presented by Alan be used to show the benefits),

- know how the data will be used (to educate or change behavior), not as a measurement of punishment,

- proven reliability and product durability, and

- participate in the decision to buy. 
Basically, it was the consensus of the group that deployment of the on-board safety technology can be accelerated for all stakeholders. The following ideas were discussed:

- For OEMs and vendors to manufacture, providing financial incentives through more FOT program support, more exposure and publicity to create the demand, and expand the FOTs to more vehicle fleet types and vehicles can accelerate manufacturing of safety systems such as the RA\&C.

- For carriers to purchase, independent evaluation of the technology that validates the positive benefit/results, provide real-life examples of successes, word of mouth recommendations from other carriers, near-term pay-offs, tax incentives (investment tax credits for IVI), accelerate depreciation, lower insurance premiums, publish the results of the FOT, expand the system to include twin-trailer benefit can accelerate purchasing of systems such as the RA\&C.

- For drivers to accept and use, outreach programs are needed to increase awareness of the technologies to the drivers. The example used by the group was videos clips (such as what Mr. Korn provided for the RA\&C). The drivers also recommended finding ways to allow drivers to use the technology for a period of time. Meritor WABCO said they were willing to provide samples to carriers free of charge for trial runs.

\section{Concluding Statements/Summary:}

The results of the discussion of motivation and deployment were summed up in a few major points ("golden nuggets”) by Mr. Pittenger.

- All interviewed stakeholders are supportive of IVI and welcome safety benefits.

- OEMs and vendors will build the systems if there are customers that are willing to pay a price that will result in a reasonable profit margin.

- Carriers and independent owner-operators will buy the systems if there is a good ROI and the initial costs are affordable.

- Drivers will use the systems if they are easy to use and they perceive that the safety systems help them do their job.

- There was a consensus of opinion from the group that both carriers and drivers are not aware of the availability and benefit of the RA\&C to their operations.

- There is a need for outreach at all levels to publicize the results of the IVI FOTs by FMCSA to their State Directors, through various organizations (CVSA, ATA, International Truck Driver Championship), published articles, video clips, and presentations at conferences beyond the ITS/IVI community. It is important to let the media know about "success stories."

- It is important to spread the word about early adopters of technology that can show and prove the effectiveness of the technology.

- Potential opportunities for other carriers to get the technology in the truck or to pilot test the technology beyond the FOT may help accelerate the adoption of new technology.

- Legislative relief to carriers for purchase should be considered, such as tax breaks and/or insurance reductions. Interviewed stakeholders are clearly looking for ways to reduce costs. 


\section{STAKEHOLDERS ATTENDING}

Vendors/Truck/Equipment Manufacturers

Rich Kempf, Manager, Technical Legislation, Navistar International

Scott Smith, Executive Engineer, Freightliner

Mark Kachmarsky, Highway Vehicle Architect, Volvo

Alan Korn, Chief Engineer, Meritor WABCO

$\underline{\text { Motor Carriers }}$

Jim Kennedy, Director of Maintenance, McKenzie Tank Lines

Thomas C. Di Salvi, Director, Loss Prevention, Schneider Trucking

Mike Connelly, Chief Safety Officer, Bowman Trucking

Keith Herzig, Owner-Operator, Herzig Trucking

Commercial Vehicle Drivers

Ed Jung, Collington Services

Wayne Sheranko, Chaney Enterprises

Keith Herzig, Owner-Operator, Herzig Trucking

Academia

Dr. Ron Knipling, Senior Research Scientist, Virginia Tech Transportation Institute

Dr. John Sullivan, Primary Researcher, University of Michigan Transportation Research Institute

Insurance

David Melton, Director of Transportation, Liberty Mutual Research Institute for Safety

Law Enforcement

Ray Cotton, Major (retired), Maryland State Police, Commercial Vehicle Enforcement Division

Professional Organizations

Dan Murray, Director of Research, American Transportation Research Institute

Steve Keppler, Director of Policy \& Programs, Commercial Vehicle Safety Alliance

$\underline{\text { Private Sector }}$

Dr. Robert McElroy, President, Forensic Accident Investigators, Inc.

\section{GOVERNMENT OBSERVERS}

\section{Federal Motor Carrier Safety Administration (FMCSA)}

Doug McKelvey, Technology Division Director

Amy Houser, General Engineer

Tim Johnson, Transportation Specialist

Debbie Freund, Senior Transportation Specialist 
National Highway Traffic Safety Administration (NHTSA)

August Burgett, Chief of Advanced Technology Research Divison

Federal Highway Administration (FHWA)

Kate Hartman, Freight Coordinator, ITS Joint Program Office

Contractors

Dawn Hardesty, Senior Systems Engineer, Mitretek

Gianluigi Caldiera, Senior Strategy Analyst, Mitretek

Battelle

Jerry Pittenger, Project Manager

Doug Pape, Senior Researcher

Dr. Mary Field, Principal Research Scientist

John Allen, FMCSA Relationship Manager 


\section{Six Workshop Questions Addressed}

1. a.) What conditions/characteristics/factors do you think impact the effectiveness of the $\mathrm{RA} \& \mathrm{C}$ to either mitigate or reduce crash severity?

b.) How effective is the RA\&C in reducing the likelihood of $1^{\text {st }}, 2^{\text {nd }}$, and $3^{\text {rd }}$ order impacts for the conditions/characteristics/factors identified? ${ }^{23}$ (Good, Fair, Poor)

a. Driver profile

i. Driving experience overall

ii. Acclamation with advanced technologies Acclimation

b. Road characteristics

i. Mountainous

ii. Ramps

iii. Freeways - urban

iv. Freeways - rural

v. Non-freeways - urban

vi. Non-freeways - rural

c. Climatic conditions

i. Snow or ice

ii. Rain

iii. Fog

iv. Windy

d. Carrier profile

i. Interstate or intrastate

ii. Long haul or short haul

iii. Large carrier or small carrier

e. Type of Truck

i. Tanker

ii. Tractor/Trailer

iii. Straight Truck

2. What secondary benefits do you envision in the adoption of a rollover advisor and controller (RA\&C) (e.g., reduction of crashes of other types)?

3. Do you think that the FOT has shown the potential for crash reductions for this on-board IVI technology? (Yes, Limited, No)

${ }^{23}$ Orders of effectiveness where:

$1^{\text {st }}$ - Technology lowers, by some percentage, the likelihood of a crash.

$2^{\text {nd }}-$ Technology lowers, by some percentage, the probability that a fatality or injury occurs if a crash occurs.

$3^{\text {rd }}$ - Technology lowers, by some percentage, the expected severity of injuries if a crash occurs. 
a. Why?

b. How do we get the message across to the carriers?

4. When/if carriers recognize the benefit of this on-board IVI technology, what is the likelihood they will buy it, and what price range do you think they might be willing to pay? (Will not buy; <\$500; <\$1,000; <\$2,000; <\$3,000; <\$5,000; >\$5,000)

5. What things do you think motivates:

a. OEMs/vendors to develop and manufacture IVI on-board technology?

b. Carriers and independent owner-operators to buy IVI on-board technology?

c. Drivers to use IVI on-board technology?

6. a. Consider the motivating factors identified in Question 5, what ideas do you have that might accelerate:

$>$ Manufacture by OEMs and vendors,

$>$ Purchase by carriers and independent owner-operators, and

$>$ Use by drivers.

b. What risks might be encountered in any effort to accelerate the introduction and acceptance of on-board safety technologies?

c. How can we best evaluate the user acceptance by carriers and drivers of an on-board safety technology?

d. How can we gather data on a large population of carriers and drivers in a costeffective way? 


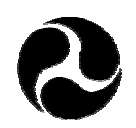

U.S. Department of Transportation

Federal Motor Carrier Safety Administration

Report No. FMCSA-MCRR-06-003
For more information on the Federal Motor Carrier Safety Administration and the Office of Research and Analysis, Check our website at www.fmcsa.dot.gov 